\title{
New information on Bostonia perplexa - an unusual member of the Calamopityaceae from North America
}

\author{
William E. Stein, Jr. and Charles B. Beck ${ }^{\mathrm{b}}$ \\ ${ }^{a}$ Department of Biological Sciences and Center for Evolution and Paleoenvironment. State University of New York, \\ Binghamton, NY 13902-6000, USA \\ ${ }^{\mathrm{b}}$ Museum of Paleontology, University of Michigan, Ann Arbor, MI 48109, USA
}

(Received September 25, 1991; revised and accepted January 15, 1992)

\begin{abstract}
Stein, W.E. and Beck, C.B., 1992. New information on Bostonia perplexa - an unusual member of the Calamopityaceae from North America. Rev. Palaeobot. Palynol., 72: 73-102.

A calamopityacean axis exhibiting multiple segments of primary xylem surrounded by secondary vascular tissue is analyzed here for its morphological and systematic significance. The plant is fundamentally protostelic with a deeply three-ribbed column of primary xylem. Each rib consists of a semi-discrete bundle of tracheids at the tip, intermittently connected to the stelar center by an extensive primary xylem parenchyma. The appearance of separate vascular segments at some levels is associated with departure of paired leaf traces. Between levels of trace departure, the three-ribbed protostele is reconstituted with primary xylem ribs following a helical course through the stem and supplying a regular Fibonacci phyllotaxis. Attached petiole bases are broadly of the Kallmma-type but exhibit a distinctly three-ribbed medial petiole bundle. The new specimen is assigned to Bostonia perplexa requiring an expanded concept of the taxon. A restricted cladistic analysis of stelar architecture and nodal anatomy within the Calamopityaceae produces two phylogenetic hypotheses. One is preferred on morphological grounds but necessitates viewing at least some protostelic calamopityaceans as exhibiting a derived condition within the group. The redefinition of Bostonia proposed here, a protostelic calamopityacean with medullosan-like vascular segments, reinforces long-standing views of a calamopityacean origin of Medullosales. Cladistic interpretation of stelar form and petiole anatomy in members of these groups. however. reveals character incompatibility hinging upon whether Quaestora (a protostelic medullosan) or Bostonia (a calamopityacean with medullosan-like dissected vascular system) should be preferred as a candidate for medullosan ancestor
\end{abstract}

\section{Introduction}

The origins and relationships of the major groups of seed plants have received renewed interest in recent years. Much valuable insight, but by no means a consensus. has been gained through different forms of analysis ranging from traditional evolutionary systematics of critical fossil specimens to broader scale morphological and phylogenetic studies (Stewart, 1983: Meyen, 1984), including cladistic methods (Crane, 1985; Doyle and Donoghue, 1986). The cladistic studies, especially those treating the relevant fossils, are particularly

Correspondence to: Dr. W.E. Stein, Jr., Center for Evolution and the Paleoenvironment, State University of New York, Binghamton, NY 13902-6000. USA. important, in our opinion, not so much for solving long-standing phylogenetic questions, which has not yet happened, but for elucidating previously obscure problem areas by increased precision of argument.

One aspect of seed plant phylogeny brought into sharp focus in this way has been the phylogenetic implications of traditional diagnostic characters at the highest taxonomic levels. In some major groups, it appears that several key synapomorphies originate together, probably as a result of being part of a large pleiotropic (or otherwise interactive) character complex established early in the history of the clade. Once this co-occurrence of features is understood, even highly fragmentary fossil specimens (e.g. isolated leaves, seeds, stems, pollen 
organs, pollen grains) are relatively easy to place with the appropriate group, and can be used to chart patterns of diversity and relationship through time. Other fossils. including some that are immediately antecedent to known major groups, are much more problematic. The fragmentary nature of most specimens contributes to uncertainty regarding their significance, but this is almost certainly not the whole story. Often these fossils exhibit unusual combinations of supposedly diagnostic features, and unprecedented variability that is difficult to circumscribe with terminology normally used to distinguish the better known groups. Within the cladistic paradigm. putative synapomorphies exhibit numerous conflicts as phylogenetic estimates (Stein. 1987) usually interpreted as homoplasy - as yet unrecognized instances of parallelism (convergence) or reversal in the character set. Unfortunately, however, this interpretation often seems unrealistic from the standpoint of morphological complexity of the characters and plausible processes of evolutionary change such as adaptation. homeosis, heterochrony, and functional constraint. Thus, results of this kind may represent a challenge to current cladistic approaches.

The fossil material described in this report, we suspect, is of the kind just discussed. Lower Mississippian permineralized stems with attached and associated petioles constitute a major fraction of the earliest record of seed plants. Most taxa share generalized features of the cycadophytic gymnosperms (Arnold, 1948) and are traditionally separated from more or less synchronous taxa (e.g. Eristophyton. Bilignea, Endoxylon, Stanwoodia) having decidedly more pycnoxylic secondary xylem (Read, 1937; Lacey, 1953; Galtier and Scott, 1989, 1991). Early seed plants with large petiole bases containing multiple vascular bundles of the $\mathrm{Kal}$ Imma-type are usually placed in the pteridosperm family Calamopityaceae (Taylor, 1981: May and Matten, 1983; Stewart. 1983; Galtier, 1988). This group is usually distinguished from the more or less synchronous seed-fern families Lyginopteridaceae and Buteoxylonaceae, characterized by leaves with a single petiolar bundle, although all taxa are poorly known as biological entities and a wide degree of overlap is observed in stelar form, petiole vascular architecture, and cortical histology. Galtier (1988), however, has provided some interesting morphometric comparisons indicating that Calamopityaceae have a uniquely high proportion of petiole to stem primary vascular volumes, as well as significantly greater amounts of cortical tissue relative to primary vascular tissues in the stem. Currently six genera of Calamopityaceae are recognized: Calamopitys (Unger, 1856), Stenomvelon (Kidston and Gwynne-Vaughan, 1912), Diichnia (Read, 1936), Bostonia (Stein and Beck, 1978), Galtiera (Beck and Stein, 1987), and Triichnia (Galtier and Beck, 1992). Several species within Calamopitys and Stenomyelon have been recognized with varying degrees of certainty in both Europe and North America (see Galtier and Meyer-Berthaud, 1989; Meyer-Berthaud. 1984, for recent discussions). Diichnia has two defined species (Beck et al., 1992) and the remaining three genera are so far all monotypic, based upon specimens either from the Lydienne Formation in the Montagne Noire of France or New Albany Shale of Kentucky, USA. For recent commentary on the Calamopityaceae, see Beck (1985). Beck and Stein (1987), Galtier (1988), and Galtier and MeyerBerthaud (1989).

Although the Calymopityaceae have figured prominently in discussions of seed plant character evolution, notably of the stele (Beck, 1970, 1976; Galtier, 1973, 1986; Rothwell, 1976; Rothwell and Erwin, 1987), their morphological significance has remained largely unexamined in cladistic studies to date. In a decidedly non-cladistic view, Meyen (1984) developed a case, based upon locality and sedimentological association in the Scottish Lower Carboniferous, for linking calamopityacean stems of the genus Stenomyelon with flattened (platyspermic) lagenostomalean Lyrasperma seeds. The resultant composite plant, further elaborated by Retallack and Dilcher (1988), comprised the earliest and most primitive member of his class Ginkgoopsida, thought to be one of three seed plant lineages independently derived from one, or possibly several, archaeopteridalean progymnosperm ancestors. These ideas have been subject to criticism for lack of evidence and explicit methodology (Beck, 1985; Miller, 1985; Rothwell. 1985, but see Meyen, 1986), for massive homoplasy when placed 
in a cladistic framework (Stein and Beck, 1987), and for the lack of consistent sedimentological association of flattened seeds with calamopityacean stems in other localities (Galtier and MeyerBerthaud, 1989).

The stelar anatomy of the Calamopityaceae as a group, notably an impressive array of primary vascular systems ranging from simple to "vitalized" protosteles in Stenomyelon and Galtiera to partly or completely eustelic forms in Calamopitys. Diichnia and Triichnia, appear tantalizingly transitional between primitively protostelic aneurophytalean progymnosperms and mostly eustelic later seed plant groups (Namboodiri and Beck, 1968; Beck, 1970) as well as, perhaps, the dissected stelar system in the Medullosales (Mapes and Rothwell, 1980). However, significant problems appear with phylogenetic hypotheses involving these taxa as intermediates. In the arrangement of protoxylem. metaxylem. and trace departure, the protostelic condition observed in both Stenomyelon and $\mathrm{Gal}$ tiera is considerably different and, perhaps, more complex than that of any known aneurophyte, increasing the likelihood that protostely per se in the two groups is not the result of inheritance from a common ancestor (Beck and Stein, 1985). Moreover, calamopityacean taxa show several perplexing combinations of stelar form, dissection, and trace departure, complicating recognition of clades within the group based upon these features, as well as the case for calamopityacean intermediacy between progymnosperms and other major seed plant groups within any specific hypothesis. Part of the problem, we suspect, is in distinguishing phylogenetically significant differences among calamopityacean taxa from ontogenetic differences in single shoot systems and from variability expected of natural populations.

Among calamopityacean taxa, none is more enigmatic than Bostonia perplexa, based on a single specimen from the Falling Run Member of the Sanderson Formation of the New Albany Shale (Stein and Beck, 1978). Only the center of the axis is preserved, but it is entirely unique in exhibiting a ground tissue containing at least three segments of primary xylem, each surrounded by its own cylinder of secondary xylem. One segment of primary xylem appears three-ribbed in transverse section and contains evidence of a pair of vascular bundles that comprise one or more incipient leaf traces. Overall, this segment is comparable to the entire protostelic system observed in the genus Stenomyelon, and in mode of trace departure appears similar to taxa exhibiting two distinct sites of trace origin, specifically the protostclic Stenomyelon hifasciculare (Meyer-Berthaud. 1984) and Galtiera bostonensis (Beck and Stein, 1987), and the eustelic Diichnia kentuckiensis (Read, 1936).

In our original paper on Bostonia (Stein and Beck, 1978), we suggested that the presence of multiple vascular segments invited comparison with the "polystelic" Medullosales. We noted, however, that a localized and false appearance of polystely might be the result of a distal branching. and concluded that assessing Medullosan relationship for Bostonia on this feature alone would be unproductive. Nevertheless, the possibility that some sort of relationship exists between at least some member(s) of the Calamopityaceae and the Medullosales is supported by both stratigraphic and morphological evidence. Bona fide members of the Medullosales, including Quaestora (Mapes and Rothwell, 1980), the only known protostelic genus, and one or more species of Medullosa (Taylor and Eggert, 1967), occur in Upper Mississippian (El stage of the Namurian A) sediments of the Fayetteville Formation of Arkansas (Mapes and Rothwell, 1980). This places them only slightly younger than typical members of the Calamopityaceae, which occur in sediments ranging from early Tournaisian to late Visean (Scott et al., 1984). In addition, although there are many apparently autapomorphic features of the Medullosales (e.g. advanced stem and leaf anatomy, complex seeds, pollen organs, and pollen), a consistently low position for this group compared with many other well-known seed plant groups seems to be a recurrent cladistic view to date (Crane, 1985; Doyle and Donoghue, 1986, 1987; Drinnan et al., 1990).

As part of an ongoing project to re-evaluate the morphological and evolutionary significance of members of the Calamopityaceae, we have discovered a second and much more completely preserved specimen exhibiting multiple vascular segments in the same stem. The purpose of this paper is to provide a description of this material, and to re- 
interpret the significance of the genus Bostonia in light of it. We have uncovered evidence that the dissected vascular pattern occurs as a regularly repeating aspect of a fundamentally protostelic calamopityacean stelar system unrelated to branching of the stem. Given this expanded view, we undertake a preliminary cladistic analysis of this taxon with regard to stelar evolution within the Calamopityaceae, and possible ancestry of the Medullosales. We then conclude with some opinions on the evolutionary significance of features observed so far, both within and outside the cladistic paradigm.

\section{Materials and methods}

The specimen described in this report was obtained from the Hoskins paleobotanical collection. originally at the University of Cincinnati but now part of the permanent collections at the Cleveland Museum of Natural History. It consists of at single axis fragment, with attached petiole bases, embedded in a block of biogenic phosphatic matrix containing a variety of other plant and invertebrate fossils (Plate I, 1-5; Plate II, I 3). Unfortunately. no locality or other identifying information was attached to the specimen, and all attempts to find a record of it have so far failed. Based upon appearance of the plant fragments and associated matrix, however, the specimen is clearly of Lower Carboniferous age and almost certainly belongs to the extensive collection from Falling Run Member of the Sanderson Formation, New Albany Shale, collected and described by Hoskins and Cross (1951a, b), and Cross and Hoskins (1951a, b).

As received. the block had been trimmed, exposing the calamopityacean axis in approximately transverse section. This raises the possibility that additional portions of the specimen may exist. but a thorough search of the Cleveland Museum collection revealed nothing. From the material in hand. we prepared a total of 13 transverse and 28 longitudinal sections using a variety of methods. Transverse sections. as large as $4.5 \times 5.5 \mathrm{~cm}$ in size, were prepared by carefully polishing an exposed surface of the block with $\# 600$ Carborundum abrasives to remove saw marks, followed by pressure mounting to a glass slide using Hillquist's A B thin-section epoxy. The specimen was then cut into thin wafers using a high-precision cut-off saw, preserving as much of the original block as possible. Glass-mounted sections were then ground to approximately $100 \mu \mathrm{m}$ thickness, first by a thinsection grinder, and then by hand using $\& 600$ Carborundum and $0.05 \mathrm{~mm}$ aluminium oxide abrasives on a glass plate. Serial transverse sections prepared in this manner are at intervals of approximately $23 \mathrm{~mm}$. Smaller transverse and longitudinal sections were embedded in Ward's bioplastic. sectioned at $1 \mathrm{~mm}$ intervals using a high-speed dental saw. and prepared using standard techniques (Stein et al., 1982). More detailed notes on preparation are deposited with the specimen at the Cleveland Museum of Natural History.

A recent survey of stratigraphy and sedimentation of the Devonian-Mississippian black shale sequence in Kentucky (Ettensohn et al.. 1988) suggests that the plant-bearing Falling-Run horizon is a lag deposit partially or completely equivalent to the lower Tournaisian Berea Bedford clastic sequence and the Sunbury shales. The beds represent the oldest occurrence of a characteristic Euramerican basal Carboniferous Calamopityacean flora known from the New Albany and equivalent shales of Kentucky. Indiana. and Missouri, the Calciferous Sandstone in northern Britain. the Lydienne Formation in the Montagne Noire of France, and equivalent formations in central Europe (see references in Scott et a1., 1984; Beck and Stein. 1987; Galtier and Meyer-Berthaud, 1989).

Associated vascular plants in the block, generally supporting this age assignment. include a petiole fragment assignable to Kalymma (Plate II. I arrow; Plate VI, 4), perhaps belonging to the main axis of our specimen but not observed in organic connection, fragments of at ground tissue or cortex containing a complex arrangement of vascular bundles and fibers assignable to SteloxyIon (Plate I, 1 arrow a: Plate II. 3), and portions of a vascular system with eustelic arrangement of primary xylem bundles around a pith surrounded by pycnoxylic secondary xylem (Plate I, I arrow b. Plate II. 3) typical of Callixy $/$ n. The latter two specimens are closely associated but do not show 
organic connection. Other vascular plants include a well-preserved axis fragment similar to Hierogramma (Plate II, 2) with possible cladoxylopsid affinities, an isolated linear primary xylem bundle with abundant secondary xylem (Plate I, 1 arrow (; 5), also reminiscent of cladoxylopsids (e.g. Xenocladia, some species of (ladoxylon), and a small fragment of aerenchymatous cortex (Plate I, 4) resembling Periastron or Aerocortex (Beck, 1978).

\section{Description}

The main axis of the calamopityacean specimen (Plate I, 1: Plate II, 1) includes portions of the stelar system, inner and outer cortex, leaf traces, and attached petiole bases. Maximum preserved diameter of the main axis, including petiole bases, is approximately $4.5 \mathrm{~cm}$. Both primary and secondary vascular tissues are preserved (Fig. 1; Plate III, 1,2). Maximum diameter of primary and secondary xylem is approximately $2.0 \mathrm{~cm}$. In transverse section at most levels, the vascular system comprises two discrete vascular segments each containing primary xylem enveloped by secondary vascular tissues (Plate III, 1). A series of sections (Fig. 1). however, indicates that the vascular segments are ephemeral. The vascular system is fundamentally protostelic comprising a partially dissected, but basically three-ribbed, primary xylem column. In regions of the axis approximately equidistant between levels of trace departure (Plate III, 2), the protostelic condition is readily apparent. Tracheids of the primary xylem are united at the center by an extensive xylem parenchyma (Plate III, 3,4) and the entire system is enclosed within a single cylinder of secondary xylem.

Secondary xylem is a compact tissue consisting of tracheids and ray cells (Plate IV, 3-5). To the outside, in the best-preserved regions, is evidence of radially aligned and heterogeneous tissue in the region of secondary phloem (Plate IV, 6-8). External to this region is an extensive cortex comprising more or less discrete inner and outer regions (Plate II. 1). The inner region consists of a mostly homogeneous tissue of parenchyma in which are embedded leaf traces (Plate V, 3-5; Plate VI, 1). and occasional clusters of cortical cells with obvious local radial architecture (Plate V, 3). The outer part of the cortex consists of a well developed system of longitudinally anastomosing radial plates of fibers embedded in a compact parenchyma (Plate II, 1; Plate V, 3; Plate VI, 3, 5).

A pair of leaf traces departs from the main axis vascular system to supply each leaf (Plate III, I; Plate V, 1. 3). These traces further subdivide producing a typical Kalymma-type petiole base observed with up to five discrete vascular bundles (Plate VI, 1). In two instances preserved (Fig. 1), the medial (and most abaxial) bundle in the are of petiolar bundles assumes a three-ribbed appearance containing a protoxylem strand near the tip of each rib (Plate V, 4; Plate VI, 1). Leaf bases exhibit cortical features similar to that of the main axis (Plate II, 1; Plate VI, 1). No evidence of epidermis is preserved in either main axis or petiole bases. The entire specimen is variably preserved ranging from being nearly complete near the distal end (Plate II, 1), to being represented only by the primary and secondary xylem and some immediately adjacent inner cortex near the proximal end.

\section{Primary xylem}

The primary xylem of the axis (Fig. 1; Plate II, 1: Plate III, 1-4) consists of three partially interconnected and radially oriented plates of tracheids mixed to greater or lesser extents with xylem parenchyma. Width of the plates in transverse section varies between 0.5 and $1.5 \mathrm{~mm}$, with the diameter of the entire primary xylem ranging from $6-14 \mathrm{~mm}$. Within the primary xylem there appear to be at least three. probably four, partially discrete and longitudinally continuous bundles of tracheids associated with limited amounts of xylem parenchyma. Three bundles occupy the tips of ribs and have various shapes in transverse section, related to partial dissection of the primary xylem system and departure of leaf traces (Fig. 1, Cl arrows a-c; Plate III, 2 arrows $(a-c)$. The fourth bundle, sometimes only weakly distinct from the other three, appears near the center of the stelar system (Fig. 1, Cl arrow d; Plate III, 2 arrow $d$ ). All bundles are interconnected at some levels in the axis by variable amounts of metaxylem tracheids and an extensive primary xylem parenchyma (Plate III, 2-4). The 
PLATE I

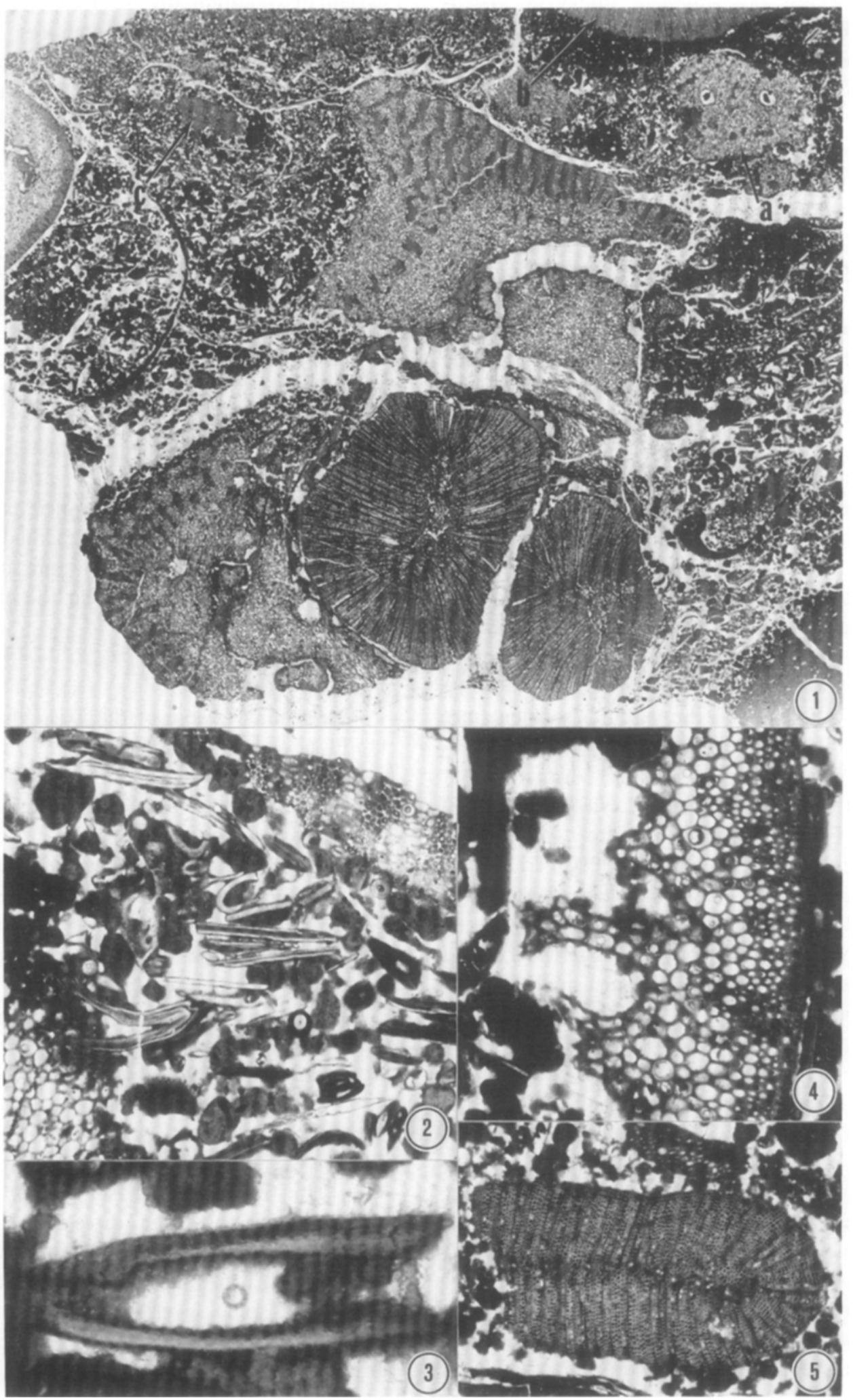


order of the primary xylem maturation is mesarch. Each of the three peripheral tracheid bundles contains one to several protoxylem strands within, or sometimes near the edge of, the major mass of metaxylem tracheids (Fig. 1; Plate III, 1,2; Plate $V, 1,2$ ).

At a "nodal" level, here defined as the level at which leaf traces separate from the primary xylem of the axis (Fig. 1, A 1, B7; Plate III, 1; Plate V, 1), one bundle of tracheids, comprising a primary xylem rib tip, is completely separated from other components of the primary xylem by secondary vascular tissues (i.e. comprises one of two vascular segments observed at this level). This bundle is itself distinctly three-ribbed with two outermost, or abaxial, subsidiary ribs comprising the sites of leaf trace production (Fig. 1; Plate III, 1 arrows). Incipient leaf traces at this level contain from one to four protoxylem strands each (Plate V, 1). The third subsidiary rib of this primary vascular segment, comprising a continuing component of the primary xylem rib of the stele, is directed toward the center of the vascular system and contains from one to several protoxylem strands, not all of which appear to be longitudinally continuous (Fig. 1, A1, B7, C1). One or more of these protoxylem strands occur in locations adjacent to each incipient leaf trace just proximal to trace departure (Fig. 1, B3 arrows; Plate V, 1 arrows). At more distal levels, these protoxylem strands become indistinct. Leaf traces separate from the primary xylem of the main axis leaving behind a much simplified primary xylem segment containing only more centrally located protoxylem strands (Fig. 1,
A1-B5 for trace system II: B3-C1 for trace system III).

Distal to leaf trace production, the three-ribbed primary xylem segment contracts, and the separation between it and the remainder of the primary xylem decreases. At approximately midway between "nodes", segments join into a three-ribbed primary xylem column with bundles of tracheids connected by an extensive central xylem parenchyma (Plate III, 2). At this level, the entire system also becomes enveloped within a single fluted cylinder of secondary vascular tissues (Plate II, 1; Fig. 1, B3, C1)

The contraction of one primary xylem rib of the vascular system distal to trace departure is associated with radial expansion of an adjacent primary xylem rib (Fig. 1, A1-B3; Plate V. 2). Beyond a certain level, this rib becomes separately enveloped by secondary xylem and thus comprises a distinct vascular segment. Distally, the primary xylem of this vascular segment exhibits an increasingly three-ribbed appearance with greater numbers of protoxylem strands, ultimately containing a pair of incipient leaf traces (Fig. 1, B3-B7). Trace departure from this rib follows in a manner similar to that described above. Evidence for the same pattern of rib elaboration, separation into a discrete vascular segment, and trace departure have been observed in succession for each of the three primary xylem ribs of the stele. A threedimensional reconstruction of the primary xylem based on available serial sections (Fig. 2) indicates that the primary xylem ribs are not fixed in position, but in fact appear to rotate through distance in the stem.

\section{PLATE I}

Cleveland Museum specimen P2001; section numbers in parentheses.

1. Transverse section of Bostonia perplexa main axis showing two distinct vascular segments, each comprised of primary and secondary tissues. Attached leaf bases, upper-right and lower left, are partly preserved. Associated plant fossils in the matrix include portions of a Kalymma petiole, upper left, a ground tissue or cortical fragment assignable to Steleoxylon, arrow a, closely associated with primary and secondary xylem of Callixylon, arrow $b$, an isolated fragment of primary and secondary xylem perhaps cladoxylopsid, arrow c. (B7), $\times 3.5$.

2. Enlargement of matrix showing many microfossil shell fragments. (B6). $\times 27$.

3. Further enlargement of the most common microfossil in the matrix consisting of thick-walled cones tapering slightly at the closed end. (B7). $\times 87$.

4. Cortical fragment in the matrix showing evidence of aerenchyma perhaps similar to Periastron or Aerocortex. (B4), $\times 22$.

5. Enlargement of a possible cladoxylopsid xylem fragment indicated in Plate I, 1 arrow $c .(B 4) . \times 19$ 
PLATE II
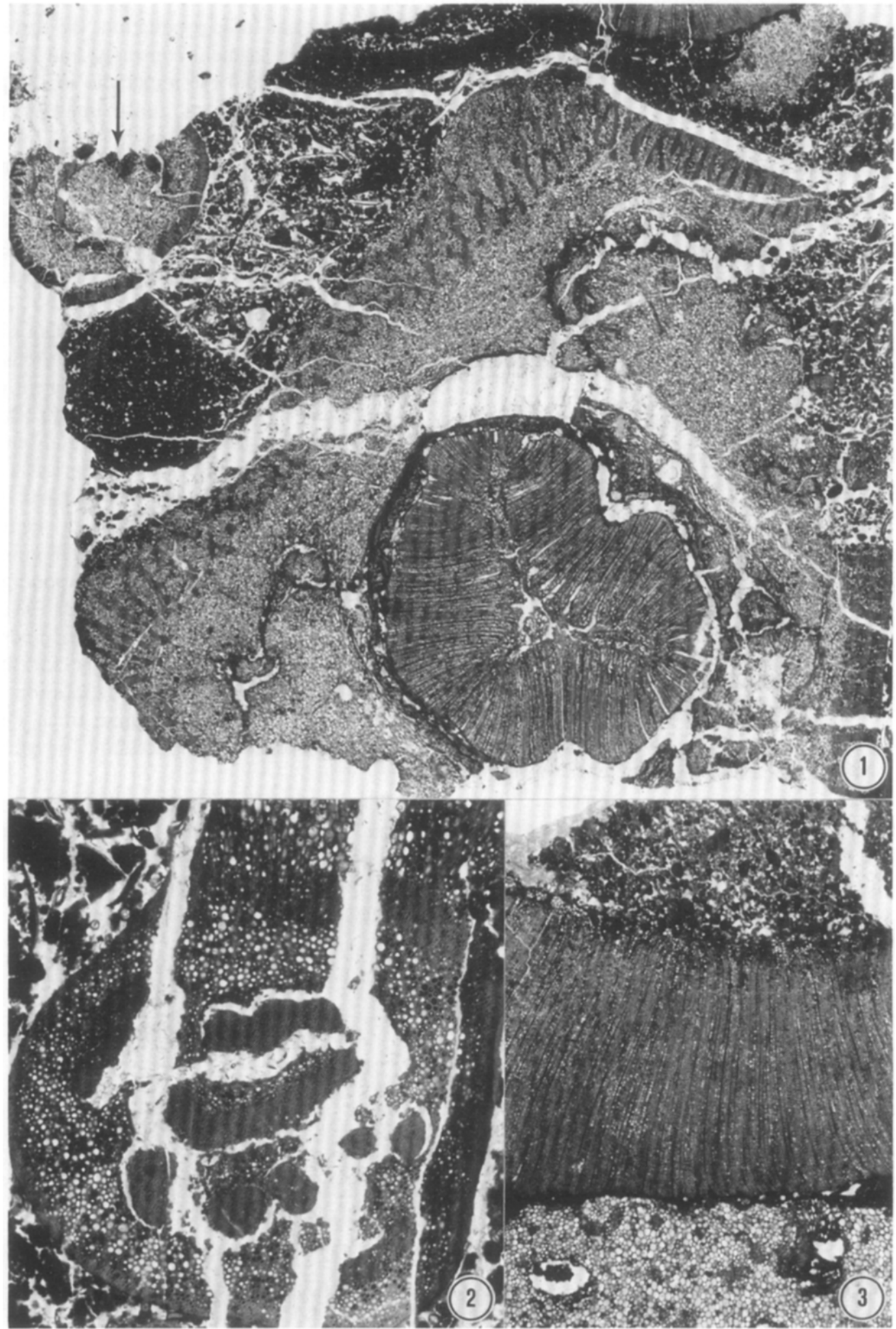


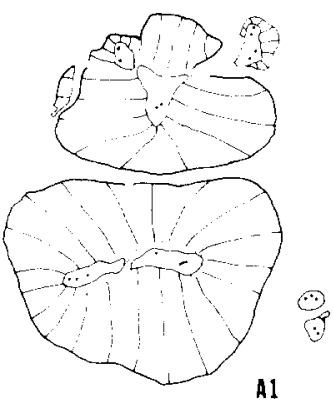

A1

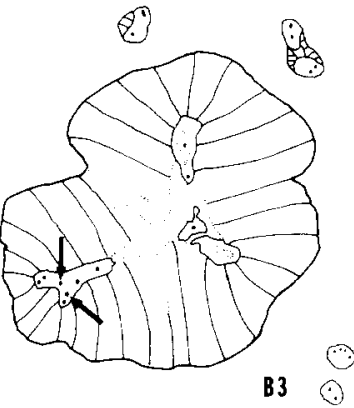

$\bigcirc$
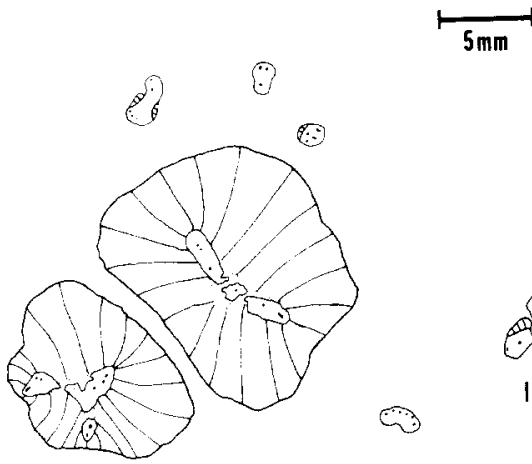

B7

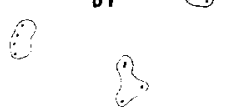

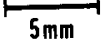

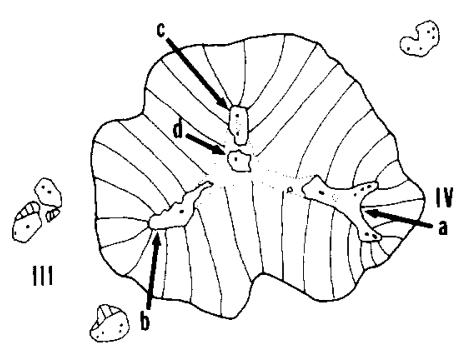

C1<smiles>[C]1C=CC=C1</smiles><smiles>IC1C=CO1</smiles>
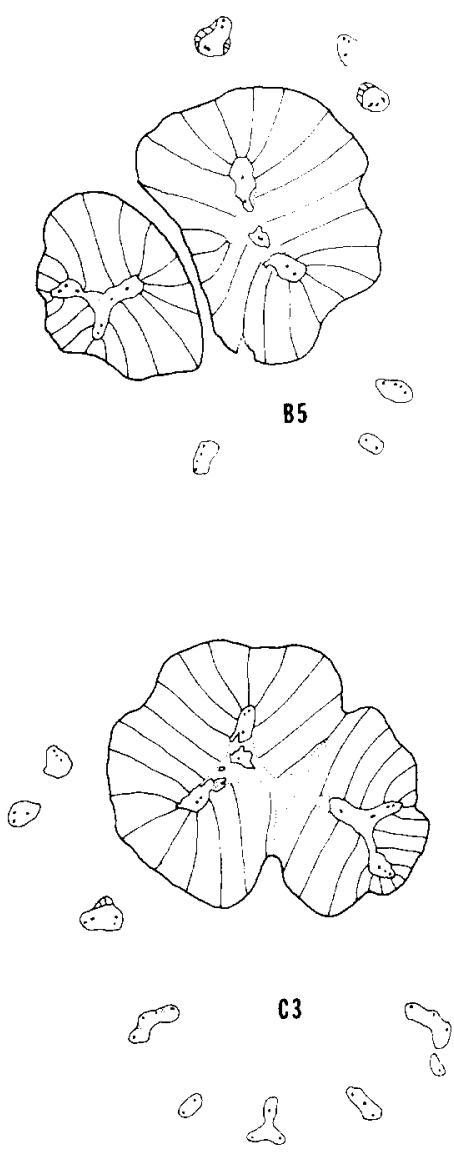

Fig. 1. Bostonia perplexa, Cleveland Museum specimen P2001. Serial camera lucida drawings showing changes in primary and secondary xylem through preserved length of the axis. Proximal section (A1), upper left, and distal section (C3), lower right. Read series from left to right starting at section Al. Longitudinally discontinuous protoxylem indicated by arrows in section B3. Semidiscrete masses of primary xylem tracheids labelled $a-d$ in section $\mathrm{Cl}$ (compare with Plate III, 2). Leaf trace systems in section $\mathrm{Cl}$ ordered according to the ontogenetic helix by roman numerals $I$ - $I V$ (compare with Fig. 3).

Both permanent and ephemeral protoxylem strands in the vascular system of the axis, incipient traces, and petiolar bundles (Plate V, 1-3) consist mostly, if not entirely, of tracheids measuring from
15-40 $\mu \mathrm{m}$ in transverse diameter. Tracheids of the metaxylem range in size up to $220 \mu \mathrm{m}$ in transverse diameter. Primary xylem tracheid pitting is not preserved. Parenchyma of the central primary

\section{PLATE II}

Cleveland Museum specimen P2001; section numbers in parentheses.

1. Transverse section of Bostonia perplexa main axis approximately midway between "nodal" levels defined by origin of leaf traces. The primary xylem at this level is protostelic, appearing deeply three-ribbed, and enveloped in a single column of secondary xylem. Associated Kalymma petiole at upper left. arrow. (C1). × 3.4 .

2. Transverse section of a plant fragment assignable to Hierogramma found associated with Bostonia perplexa. Note multiple primary xylem bundles and characteristic cortex. (4Al-2). $\times 11$.

3. Transverse section of pith, primary xylem, and pycnoxylic secondary xylem of a plant fragment perhaps assignable to Callixylon found associated with Bostonia perplexa. Outside these vascular tissues, bottom, is closely associated, but apparently not attached, cortical or ground tissue assignable to Steloxylon. (A1). $\times 9.6$. 
xylem in "internodal regions" occurs in a large mass near at the center of the primary xylem (Plate III, 4; Plate IV , 1), narrowing into large multiseriate primary rays in the first formed secondary xylem (Plate IV, 2) and becoming scattered among the tracheids of the peripheral and central primary tracheid bundles (Plate III, 3). Individual cells are approximately $40-80 \mu \mathrm{m}$ in transverse diameter and are uniformly short, usually between 30 and $60 \mu \mathrm{m}$ in height.

\section{Secondary vascular tissues}

Secondary vascular tissues occur in one or two columns of radially aligned cells depending upon level in the axis (Fig. 1). In internodal regions where secondary xylem comprises a single column (Plate III, 2), it is distinctly fluted reflecting the underlying three-ribbed configuration of the primary xylem, although correspondence in shape is not exact. Secondary xylem varies in thickness from $6.0 \mathrm{~mm}$ approximately midway between primary xylem ribs, to as little as $0.6 \mathrm{~mm}$ thickness near the tip of the most extended primary xylem rib.

Only tracheids and ray cells have been observed in the secondary xylem (Plate III, 3,4; Plate IV, $2.3)$. Tracheids appear rectangular to polygonal in transverse section and exhibit variable size but no distinct size zonations as might be expected of growth increments. Individual tracheids range between 40 and $80 \mu \mathrm{m}$ tangential width, and between 40 and $120 \mu \mathrm{m}$ radial width, measured in transverse section, with some observed to exceed several millimeters in length. Pitting, although poorly preserved, is recognizable by a regular pattern of granularity in radial wall surfaces in radial section (Plate IV, 4), and bordering the compound middle lamella in sectional view in tangential sections (Plate IV, 5). Available evidence suggests that pit pairs are multiseriate and alternate, probably restricted to radial wall faces.

The vascular rays in the secondary xylem are mostly uniseriate or biseriate, flaring to conspicuously multiseriate in the embayments between primary xylem ribs (Plate IV, 2) and intergrading with the extensive xylem parenchyma of the center of the primary xylem (Plate IV, 1). Conspicuous dilation also occurs irregularly at the periphery of the secondary xylem near the tips of primary xylem ribs and in facing secondary xylem wedges of separate vascular segments (Plate III, 1-2; Plate V, 1-2). Individual rays vary from being short to apparently many cells in height and, judging from generally uniform preservation, are probably comprised exclusively of parenchyma. Tangential sections of mostly multiseriate rays of the inner secondary xylem are as large as $0.3 \mathrm{~mm}$ (5-6 cells) in width and $4 \mathrm{~mm}$ in length. All rays exhibit cells usually between 40 and $60 \mu \mathrm{m}$ in height, and often $40 \mu \mathrm{m}$ or less in tangential width. Poor preservation precludes reliable measurement of other dimensions.

External to the secondary xylem is a variably preserved region, in the position of secondary phloem, ranging approximately from $0.7-1.7 \mathrm{~mm}$ in radial thickness. This region contains at least two kinds of cells. Most conspicuous are cells

\section{PLATE III}

Bostonia perplexa. Cleveland Museum specimen P2001; section numbers in parentheses.

1. Transverse section of the vascular system close to the level of leaf trace departure. A pair of incipient leaf traces, arrows. (B6). $\times 5.1$

2. Transverse section of the protostelic and deeply three-ribbed primary xylem system in an "internodal" region defined by trace departure. The tip of each primary xylem rib is represented by semi-discrete masses of tracheids linked by intervening primary xylem parenchyma, arrows $a-c$. A central mass of tracheids perhaps representing the center of the stelar system, arrow $d$. (C1). $\times 5.1$.

3. Transverse section. enlargement of a portion of the three-ribbed primary vascular segment in Plate III, 2. showing arrangement of primary and secondary xylem tracheids. Periphery of stem toward the top. Protoxylem of incipient trace. upper right. less conspicuous and apparently discontinuous protoxylem, center and left. (C1). $\times 7.4$.

4. Continuation of the region in the previous photograph. Protoxylem of continuing cauline portion of three-ribbed primary vascular segment, top: primary xylem parenchyma at the center of the stele, center and bottom. (Cl). $\times 7.4$ 
PLATE III

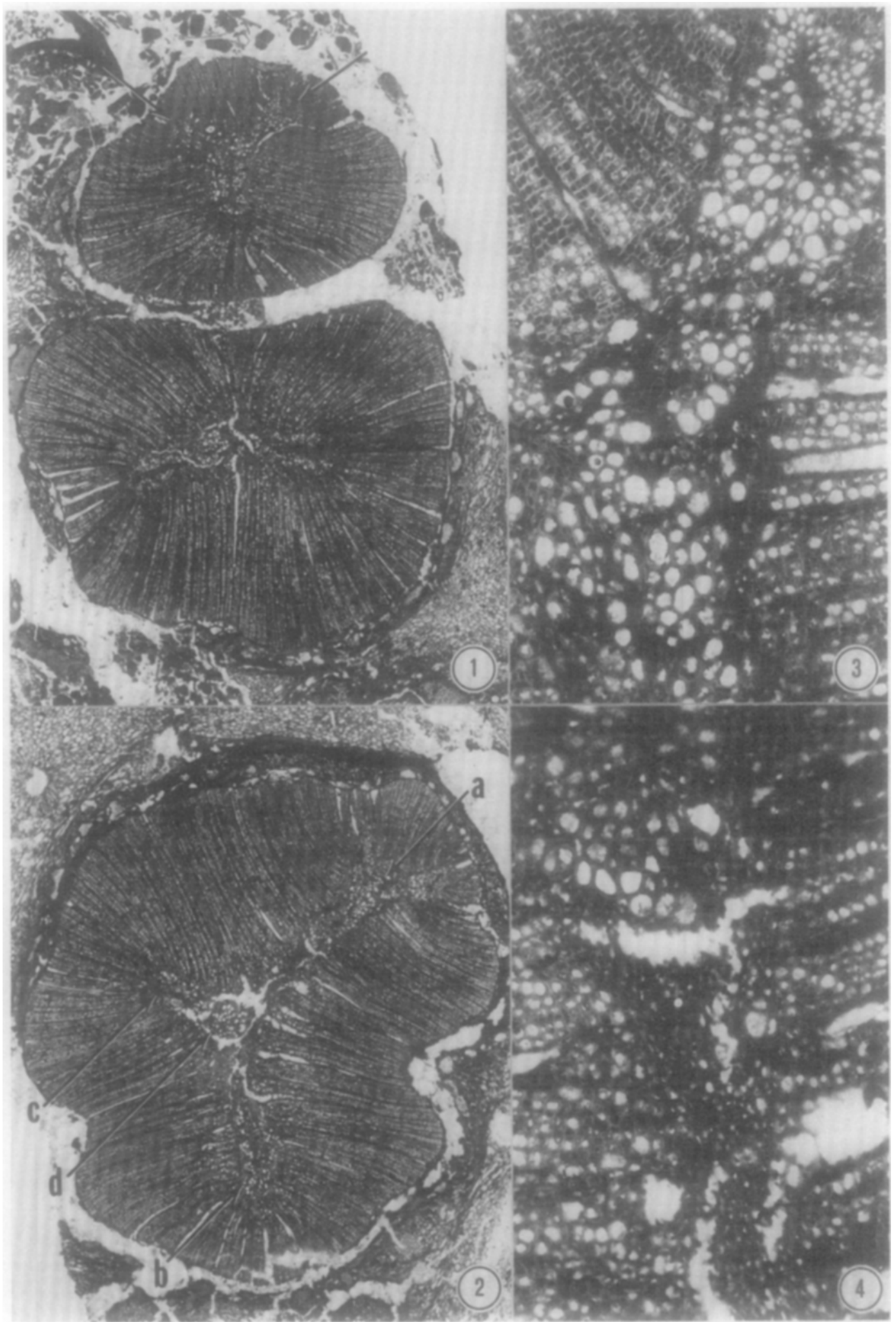


PLATE IV

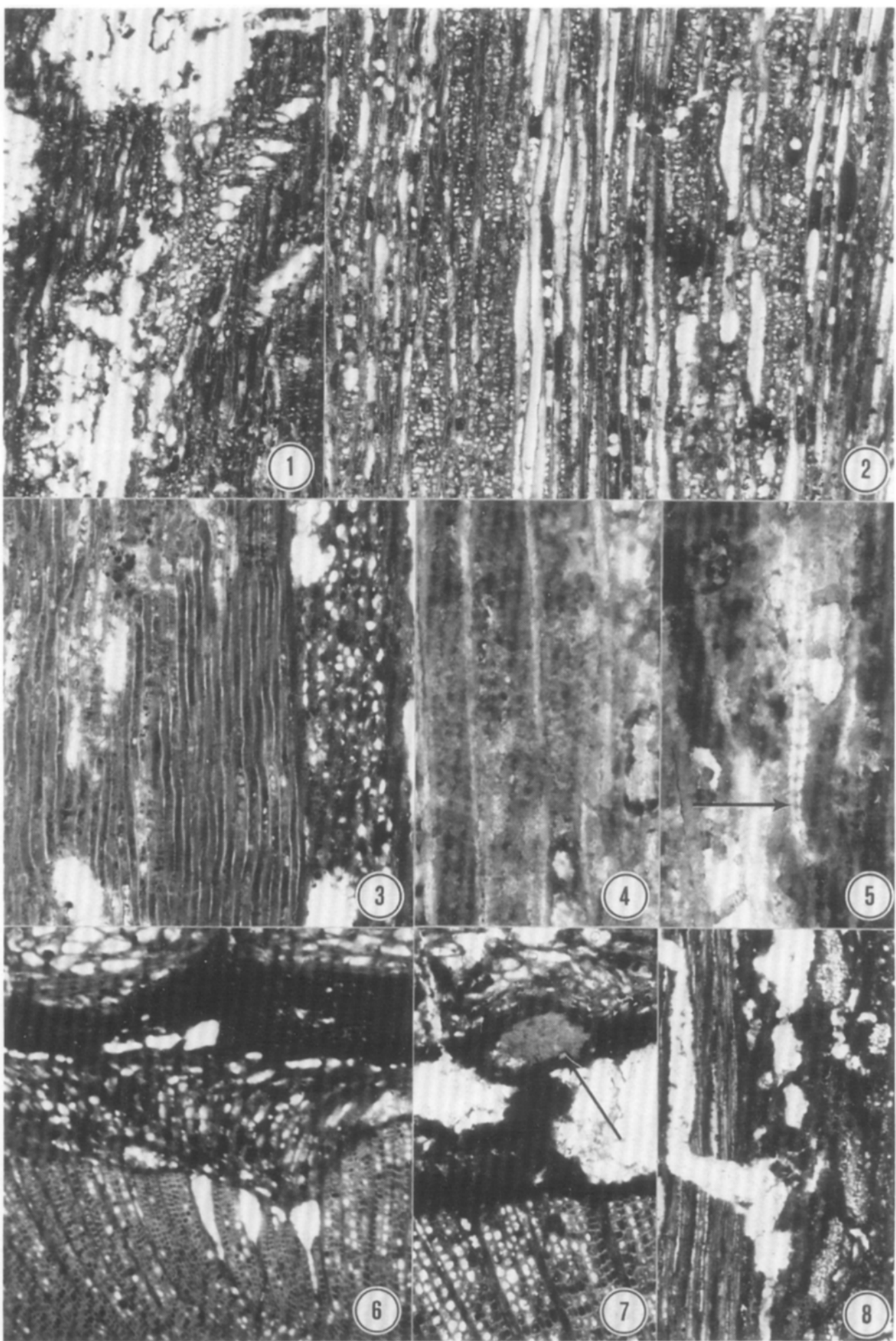


occurring in definite radial files that in some instances span the entire width of the tissue region (Plate IV , 3, 6). Due to poor preservation, however, it is not certain that these cells constitute a continuation of radial files of outer secondary xylem. In transverse section, individual cells range between 40 and $80 \mu \mathrm{m}$ tangentially, as much as $200 \mu \mathrm{m}$ radially, and have relatively thick walls. In longitudinal section, cells of this tissue are variable in size and form usually ranging from 30 and $90 \mu \mathrm{m}$ in height.

A second type of element in the region of presumed secondary phloem are isodiametric to longitudinally elongate clusters of cells occurring immediately adjacent to, as well as somewhat separated from. the secondary xylem (Plate IV, 7.8). Most cells in these clusters are approximately isodiametric, ranging between 50 and $110 \mu \mathrm{m}$ in diameter and appear thin-walled and empty. We suspect that this appearance is largely preservational artifact, however, because cells appear to have been relatively resistant to crushing compared with adjacent tissues. Moreover, some clusters contain somewhat unusually preserved cells which may be interpreted as having conspicuously thickened walls (Plate IV, 7, arrow), suggesting that they are macrosclereids. In some regions (Plate IV, 8: Plate V. 3). clusters of presumed macrosclereids comprise a system of regularly spaced longitudi- nally elongate bundles interwoven with thin sheets of crushed cells. The latter may represent the location of conducting elements of the secondary phloem, but poor preservation prevents identification of other cell types in this region. The development of secondary vascular tissues is apparently extensive enough in this specimen that no evidence of primary phloem remains. In well-preserved regions of the specimen, the periphery of the secondary tissues consists of a relatively distinct boundary of crushed cells (Plate III, 1,2; Plate IV, 6,7; Plate V, 3) which, based on cell size and wall thickness. were probably originally part of the inner cortex.

\section{Leaf traces}

The specimen includes evidence of the vascular supply for four adjacent leaves, observed either departing from the stele or in the inner cortex of the stem (Fig. 1, trace systems I-IV). Harmonic analysis of divergence angles (Stein and Beck, 1986) indicates a lax, helical, approximately Fibonacci phyllotaxis (Figs. 3,4). There is insufficient axis length to follow any single trace system to the level of petiole separation. Interpretation is therefore a composite derived from partially overlapping views of all traces. Pairs of incipient traces are preserved in three instances (Fig. 1, trace sys-

\section{PLATE IV}

Bostonia perpleva. Cleveland Museum specimen P2001; section numbers in parentheses.

1. Longitudinal section of primary xylem at approximately the level of Plate III, 2. Extensive primary xylem parenchyma at the center. $(\mathrm{CI}-18 \mathrm{~L}) \times 16$.

2. Tangential section of the inner portion of the secondary xylem showing multiseriate rays typical of this region along with narrower rays characteristic of the more peripheral secondary xylem. $(\mathrm{Cl}-22 \mathrm{~L}) \times 19$.

3. Radial section of the outer secondary xylem and peripherally adjacent tissues interpreted as comprising part of the secondary phloem. $(\mathrm{Cl}-23 \mathrm{~L}) . \times 31$.

4. Radial section of outer secondary xylem tracheids showing evidence of circular bordered pit pairs in face view. (CI-17L). $\times 170$.

5. Tangential section of outer secondary xylem tracheids showing bordered pit pairs of radial walls in sectional vicw, arrow. $(\mathrm{CI}+12 \mathrm{~L}) \times 170$

6. Transverse section of outer secondary xylem and peripherally adjacent cells in the region of secondary phloem. These cells. appearing radially elongate, are probably the same as those shown in Plate IV, 3. Externally is a zone of crushed cells. probably inner cortex. (C3). $\times 23$.

7. Transverse section of outer secondary xylem and region of secondary phloem. Arrow indicates cluster of poorly preserved macrosclereids surrounded by dark materials probably representing the remnants of adjacent cells. (C3). $\times 27$.

8 . Longitudinal section of outer secondary xylem and adjacent region of secondary phloem showing longitudinally elongate masses of cells appearing thin-walled but interpreted as macrosclereids. (CI-I3L). $\times 13$. 
PLATE V

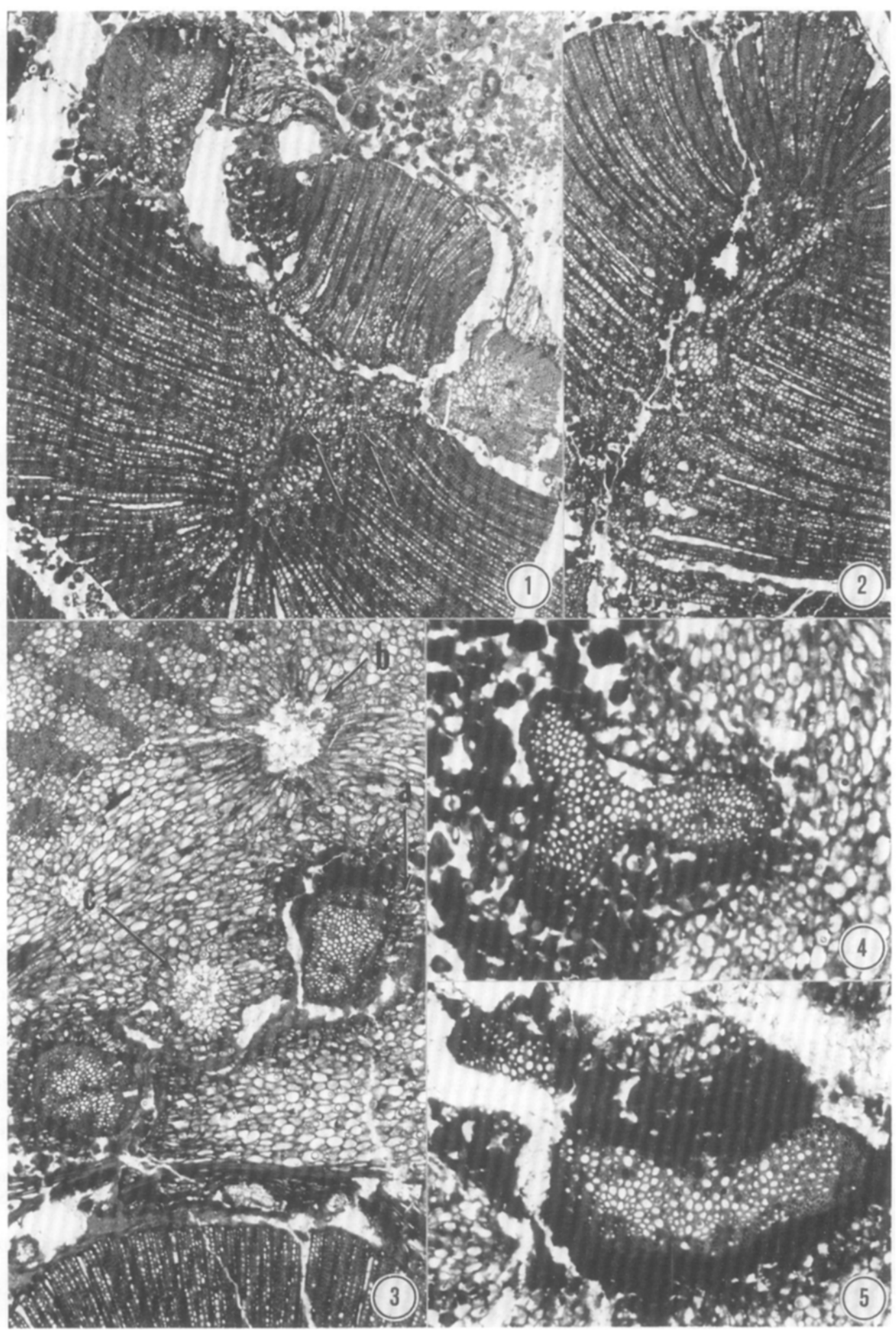


tems II-IV). These consist of primary xylem bundles departing at approximately $45^{\circ}$ to the left and to the right of the midplane of the parent primary xylem rib (Plate III, 1, arrows). The bundles comprising each pair of leaf traces are somewhat unequal in size and number of protoxylem strands at any particular level in the axis, with the trace at a smaller divergence angle to the proximally adjacent leaf (i.e., opposite to the direction of the ontogenetic helix) invariably departing from the primary xylem slightly below the other (Fig. 1; Plate III. 1.2; Plate V. 1). At a level just above separation of leaf traces from the main axis primary xylem, observed in two instances (Fig. 1, A1,B3, trace system II; B7,C1, trace system III), free traces appear elliptical in transverse section and contain from two to four protoxylem strands each. The primary xylem of each trace measures approximately $0.8 \mathrm{~mm}$ in minimum width, to a much as $2.0 \mathrm{~mm}$. In most instances, the primary xylem is accompanied by incomplete wedges of secondary xylem ranging up to approximately $1 \mathrm{~mm}$ in thickness. In several instances, individual traces are surrounded by cells that in transverse section appear similar to radially elongate cells occurring in radial files in the secondary phloem region of the main axis. Interestingly in some instances (Plate V, 3 arrows $a$ ), however, these cells also occur adjacent to petiolar bundles exhibiting little or no evidence of secondary xylem.

In the inner cortex, an initial pair of leaf traces further subdivides resulting in as many as five petiolar bundles in attached petiole bases (Fig. 1, trace systems I-III). Secondary xylem diminishes with increasing distance from the stele, until lost 1-2 mm above the level of trace departure (Fig. 1, trace systems II,III). In both instances observed, the lower departing leaf trace of an original pair, is the first to subdivide in the cortex. This first division produces daughter bundles with different forms distally (Fig. 1, trace system II). The outer (i.e. lateral) daughter bundle becomes irregularly crescent shaped with several mostly laterally placed protoxylem strands. By contrast, the other more medially (and abaxially) located daughter bundle becomes progressively three-ribbed containing a protoxylem strand near the tip of each rib.

Only one leaf shows evidence of the vascular supply beyond the level described above (Fig. 1, trace system I). Here, five variously shaped vascular bundles are arranged in a crescent with its convex surface directed away from the center of the stem (Plate VI, 1). In transverse view, the lateral petiolar bundles are themselves conspicuously crescent-shaped (Plate V, 5), and at this level have a maximum width of $0.6-1.0 \mathrm{~mm}$ and length of $3.0-4.7 \mathrm{~mm}$ measured along their curving medial contour. As many as six protoxylem strands are observed in each lateral bundle, all located near the outer surface (Plate V, 5). The medial petiolar bundle, probably corresponding to the central three-ribbed bundle of trace system II, is radially symmetrical and deeply three-ribbed (Plate V, 4), and becomes progressively more so distally over the short distance it is preserved (Fig. 1, B7,C3). Distally, the primary xylem of this bundle

\section{PLATE V}

Bostonia perplexa, Cleveland Museum specimen P2001; section numbers in parentheses.

1. Transverse section of three-ribbed primary xylem segment of the main axis at the level of departure of trace system II; compare with Fig. 1. Incipient leaf traces, upper left and center right. Longitudinally discontinuous protoxylem of the parent primary xylem rib, arrows. $(\mathrm{Al}) . \times 10$.

2. Transverse section of primary xylem rib showing origin of leaf trace system III, upper right, and attachment to the rest of the stele by an extensive primary xylem parenchyma, lower left. Compare with Fig. 1. (B2). $\times 10$.

3. Transverse section of portions of leaf trace system 1 in the inner cortex of the main axis; compare with Fig. I. Cells similar to those in region of secondary phloem of main axis, arrow a, clusters of cells showing local radial architecture in inner cortex, arrows $b$ and $c$ (B7). $\times 12$.

4. Transverse section of central vascular bundle of leaf base I; compare with Fig. 1. Note distinct three-ribbed configuration with the rib at right pointing toward the center of the stem. (C3) $\times 18$.

5. Transverse section of one lateral vascular bundle of leaf base I: compare with Fig. 1. Protoxylem strands occur on the outer, convex side, bottom. (C3). $\times 18$. 
PLATE VI

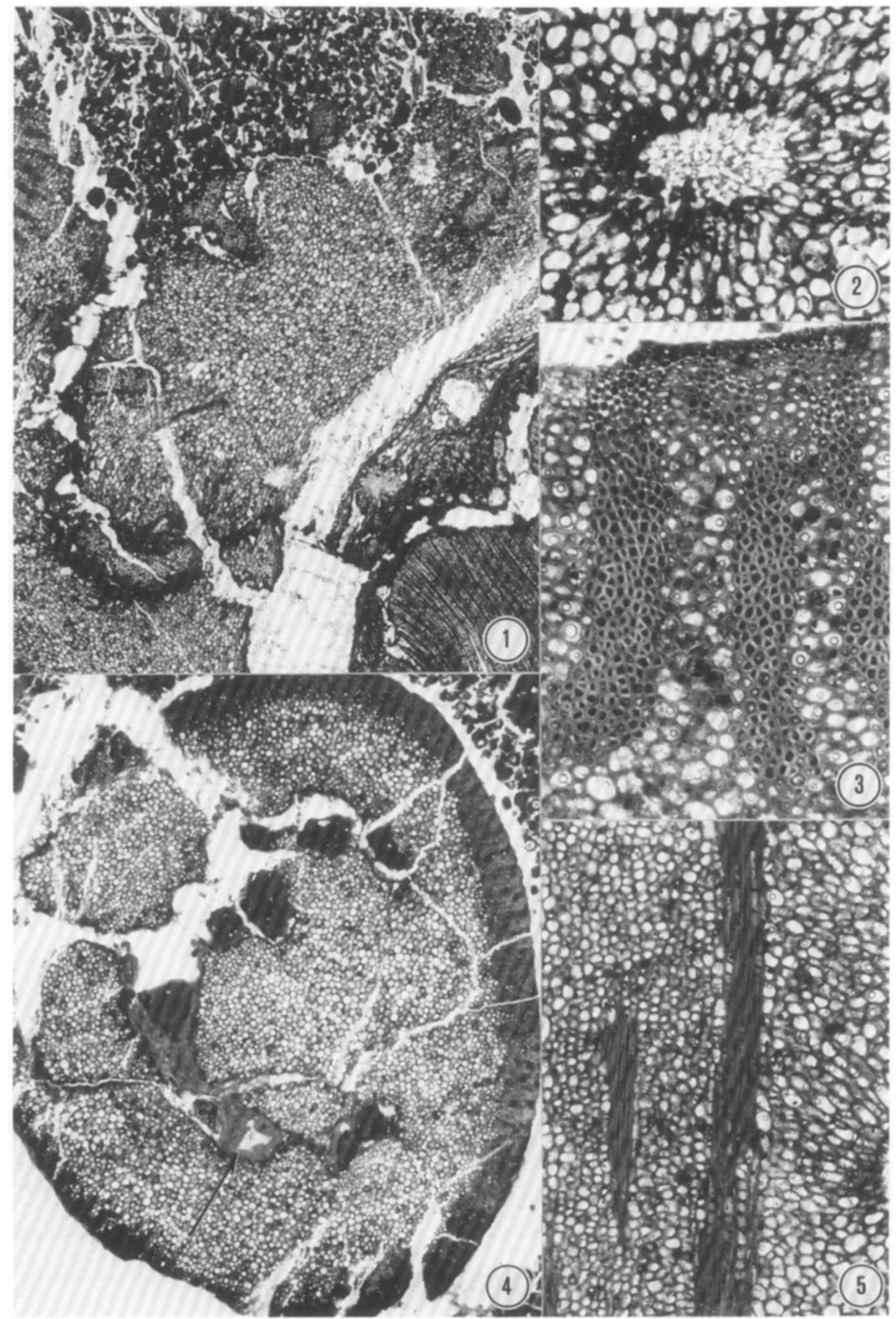


is approximately $2.3 \mathrm{~mm}$ in radial dimension, and a single protoxylem strand occurs near the tip of each rib. The rib directed toward the center of the petiole base appears partly constricted suggesting the possibility of a distal division of this petiolar bundle in the leaf's sagittal plane. In addition to crescent-shaped and three-ribbed petiolar bundles described above, the vascular system of this leaf also contains a pair of petiolar bundles, one on each side of the central three-ribbed bundle (Fig. 1, trace I). These bundles are radially elongate in transverse section, measuring approximately $0.6 \mathrm{~mm}$ in width tangentially, and between 1.3 and $2.0 \mathrm{~mm}$ in radial extent. Both petiolar bundles contain protoxylem strands near the inner and outer edges, and one bundle also has a protoxylem strand near the center (Fig. 1, C1,C3, trace system I). Petiole bundles at the most distally preserved level consist of primary xylem tracheids only. Protoxylem tracheids measure between 20 and 40 $\mu \mathrm{m}$ in transverse diameter with the metaxylem cells ranging up to $140 \mu \mathrm{m}$ in transverse diameter.

\section{Cortex}

The inner cortex (Plate II, 1; Plate V, 1; Plate VI, 1) consists of a parenchymatous tissue mostly comprised of isodiametric to mildly elongate cells of varying sizes, shapes and orientations. Typical cells in this region are thick-walled, ranging in transverse diameter $80-350 \mu \mathrm{m}$, and approximately the same in length. Also embedded in this tissue region are numerous ellipsoidal cell clusters (Plate V, 3 arrows $b$ ). Many clusters appear empty at their center, probably due to poor preservation.
Some clusters contain a discrete core of apparently thinner-walled isodiametric parenchyma. In longitudinal section (Plate VI, 2), cells of the core are arranged in axial columns and are typically shorter than they are wide. Typical longitudinal dimension ranges between 8 and $50 \mu \mathrm{m}$ with transverse diameters between 16 and $100 \mu \mathrm{m}$.

In addition to conspicuous cell clusters in the inner cortex, other regions are distinguished by slightly smaller and more uniform cell size and a hint of radial elongation in adjacent cells (Plate $\mathrm{V}$, 3 arrow c). Cells toward the center of these regions have approximately the same cell wall thickness and size as surrounding cortical parenchyma, and it seems likely that these regions represent grazing tangential sections of the more conspicuous clusters described above. However, spacing of our sections does not rule out clusters at different stages in development, or of more than one type.

The outer cortex of the specimen is of the Sparganum-type, consisting of a compact parenchyma in which are embedded longitudinally anastomosing groups of thick-walled fibers (Plate II, 1; Plate V, 3; Plate VI, 3). The groups of fibers vary from being radially elongate plates, to variously $\mathrm{Y}, \mathrm{W}$, or more complex arrangements as observed in transverse section. Radial extent of the fibrous region varies from $1.7 .3 .6 \mathrm{~mm}$ or more in somewhat oblique petiole bases. Individual fibers (Plate VI, 3, 5) average between 40 and 80 $\mu \mathrm{m}$ in transverse diameter, and are many times longer than wide with tapered ends. Parenchyma associated with the fibers occurs in more or less conspicuous longitudinal and tangential files possibly indicative of expansion of the outer cortex

\section{PLATE VI}

Bostonia perplexa. Cleveland Museum specimen $\mathrm{P} 2001$; section numbers in parentheses.

1. Transverse section of leaf trace base 1; compare with Fig. 1. Secondary xylem of the main axis, lower right. Note configuration of the five vascular bundles present at this level. $(\mathrm{Cl}) . \times 5.8$.

2. Longitudinal section of inner cortical cell cluster with local radial architecture. Compare with Plate V. 3. Note thin-walled cells in the center of the cluster apparently occurring in longitudinal columns. (Cl-19L) $\times 28$

3. Transverse section of outer cortex showing radially oriented plates of fibers and intervening, somewhat tangentially elongate parenchyma. (B7). $\times 33$.

4. Transverse section of Kalymma-like petiole associated with the main axis. Compare with Plate I,1 and Fig. 3. Main axis is toward the right. Arrow indicates location of missing petiolar bundle. $(\mathrm{CI}-3-6) \times 9.5$.

5. Longitudinal section of cortex. Bundles of fibers in the outer cortex separated by intervening parenchyma in more or less longitudinal columns, center and left; inner cortex extreme right. (Cl-23L). $\times 19$. 


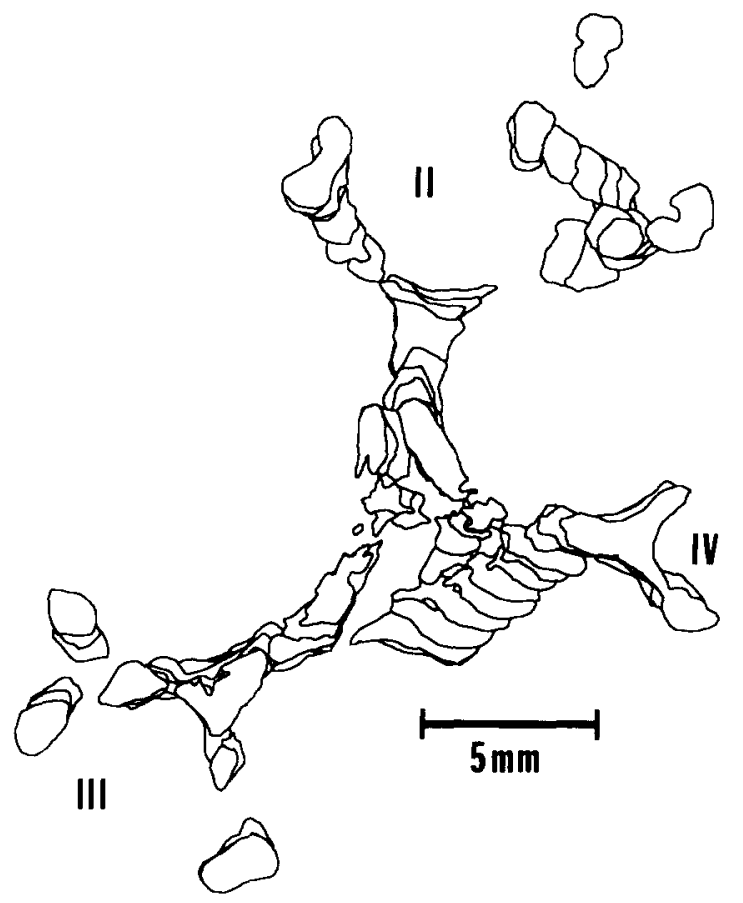

Fig. 2. Bostonia perplexa, Cleveland Museum specimen P200L. Stack of transverse sections illustrating semi-discrete masses of tracheids of the primary xylem viewed from distal end. Extension and contraction of primary xylem ribs can be observed along with regular lateral shifts in position of the ribs in the direction of the ontogenetic helix. Order of leaf traces are indicated with roman numerals, see Figs, 1 and 3 for comparison.

during development. Individual cells range between 60 and $160 \mu \mathrm{m}$ in transverse diameter, and between 60 and $280 \mu \mathrm{m}$ in height.

\section{Detached petiole}

A detached petiole of the Kalymma-type lies approximately parallel to the main axis described above (Plate I. I; Plate II, 1 arrow; Plate VI, 4). It is not attached nor, possibly due to poor preservation, does it contain evidence of the three-ribbed petiolar bundle observed in the attached petiole bases. However, it occurs in the correct orientation relative to the stem and can be interpreted as belonging to the shoot phyllotaxis (Figs. 3,4). This petiole consists of primary tissues only. Eight petiolar bundles are preserved embedded within a crescent-shaped region indicating the approximate limit of vascular tissues (Plate VI, 4). In addition,

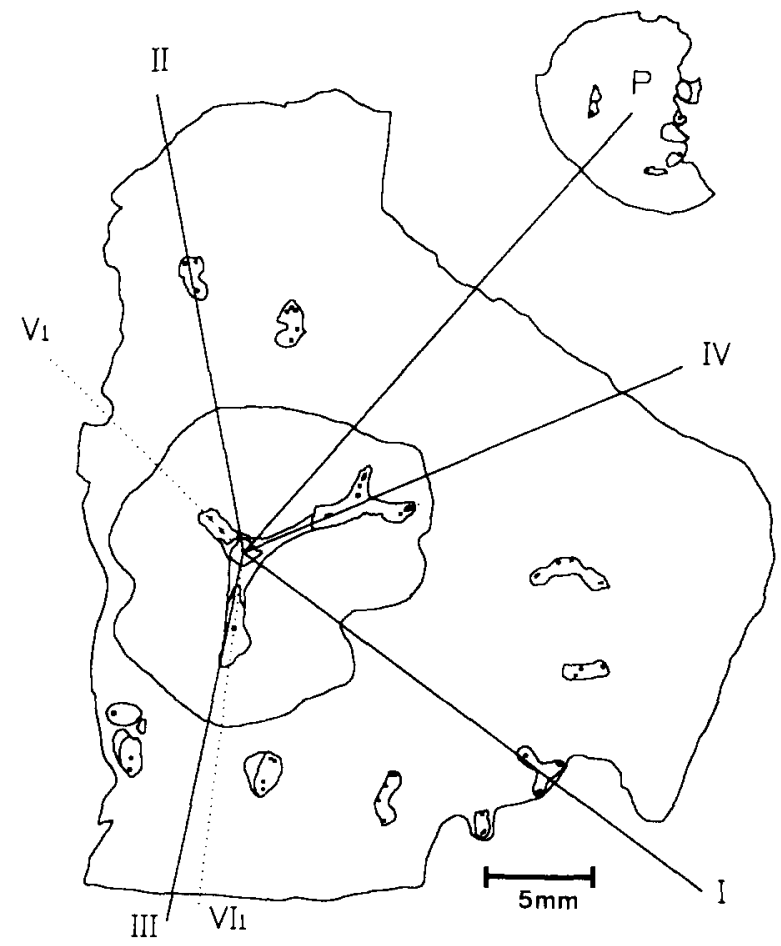

Fig. 3. Bostonia perplexa, Cleveland Museum specimen P2001. Analysis of the angular configuration of leaves in this specimen. $I-I V$. solid lines, indicate observed leaf traces; (see Fig. I for comparison). Leaf traces $V i$ and $V I i$, dotted lines, represent presumed locations of the next two incipient traces along the ontogenetic helix. $P$ indicates the location of the detached Kallmma petiole and may be interpreted as occurring in the same ontogenetic helix with an intervening leaf (not preserved) occurring in the ontogenetic helix between $P$ and $I$.

the varying width of the vascular region indicates that at least one additional bundle was probably present but is not preserved (Plate VI, 4 arrow). Due to its fragmentary condition, no change in number or position of petiole bundles could be observed over its length making identification of proximal and distal ends uncertain. Surrounding the vascular region is a parenchymatous tissue containing only occasional evidence of radial cell clusters like those described in the main stem above. The outer cortex of the petiole consists of a compact tissue with anastomosing plates of fibers similar to that observed in the stem, although showing fewer parenchyma cells between plates of fibers. The whole tissue is also less extensive, averaging $0.5-0.8 \mathrm{~mm}$ in radial extent. Individual fibers measure between 30 and $50 \mu \mathrm{m}$ in transverse 


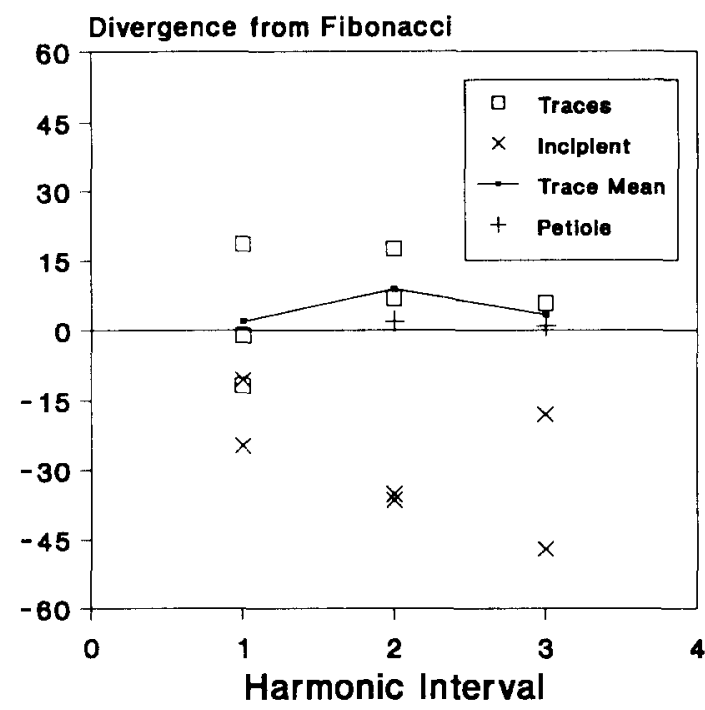

Fig. 4. Bostonia perplexa, Cleveland Museum specimen P2001. Angular configuration of leaves in this specimen relative to a Fibonacci primary divergence angle of approx. 137.5". Ordinate indicate Harmonic Interval $(H I) . H I=1$ denotes angular measurement between adjacent leaves along the ontogenetic helix (primary divergence angle); $H I=2$ denotes angle between every other leaf along the ontogenetic helix (secondary divergence angle): $H I=3$ denotes angle between every third leaf. Abscissa indicates deviation from the expectation of Fibonacci phyllotaxis for each pairwise measurement of leaves. Actual measurements very close to the Fibonacci expected will fall along the zero line. Boxes indicate pairwise measurements between observed traces $I-I V$. Pluses indicate pairwise measurements between $P$ and traces $I-I I$. Both sets of measurements indicate values close to expected Fibonacci phyllotaxis. A grand mean for each $H I$. using the above two kinds of measurements, is indicated by the small dots connected by lines. $X$ indicates pairwise measurements between traces $V i-V I i$ and $I-I V$. These measurements deviate considerably from Fibonacci expected probably because $V i$ and $V / i$, orientations of primary xylem ribs, do not accurately reflect the positions of leaves.

diameter. The petiole has not been observed in longitudinal section.

\section{Systematics}

LYGINOPTERIDALES

CALAMOPITYACEAE

Genus Bostonia Stein and Beck 1978. Am. J. Bot., 65: $459-465$
Emended diagnosis: Plants, represented by main axis and attached petiole bases, containing both primary and secondary vascular tissues. Primary xylem mesarch, protostelic, three-ribbed, comprised of three semi-discrete masses of tracheids at the tips of the ribs plus additional tracheids at the stelar center. Ribs of the primary xylem shifting in position related to production of leaf traces, segregating into two or more vascular segments, each segment comprising both primary and secondary vascular tissues. Secondary xylem with rays one to several cells in width, short to very tall; tracheid pitting alternate multiseriate bordered. Leaf vascular supply derived from a pair of leaf traces produced from a detached, threeribbed vascular segment. Cortex consisting of inner region containing clusters of cells with local radial architecture, and an outer cortex consisting of radial plates of fibers and intervening parenchyma. Petiole bases of the Kalvmma-type, developing a medial three-ribbed primary xylem bundle.

Bostonia perplexa Stein and Beck 1978. Am. J. Bot., 65: 459-465

Emended diagnosis: Diameter of primary xylem between 6 and $14 \mathrm{~mm}$; primary xylem ribs $0.5-1.5 \mathrm{~mm}$ in transverse width, varying greatly in radial extent associated with trace departure. Protoxylem tracheids $15-40 \mu \mathrm{m}$ in transverse diameter. Metaxylem tracheids as large as $220 \mu \mathrm{m}$ in transverse diameter. Parenchyma of the primary xylem $40-80 \mu \mathrm{m}$ in transverse diameter, uniformly short $30-60 \mu \mathrm{m}$ in length. Secondary xylem 0.6$6.0 \mathrm{~mm}$ in transverse thickness with vascular rays up to $0.3 \mathrm{~mm}$ in width, $4 \mathrm{~mm}$ in length; individual tracheids $40-80 \mu \mathrm{m}$ in tangential width, $40-120 \mu \mathrm{m}$ in radial width, and several $\mathrm{mm}$ in length; ray cells $40-60 \mu \mathrm{m}$ in height, up to $40 \mu \mathrm{m}$ in tangential width. Secondary phloem region containing radial files of probable parenchyma $40-80 \mu \mathrm{m}$ tangential width, up to $200 \mu \mathrm{m}$ in radial width, $30-90 \mu \mathrm{m}$ in height, and longitudinally elongate clusters of macrosclereids $50-110 \mu \mathrm{m}$ in diameter. Cells of inner cortex $80-350 \mu \mathrm{m}$ in diameter with imbedded clusters of thin-walled cells $16-100 \mu \mathrm{m}$ in transverse and $8-50 \mu \mathrm{m}$ in longitudinal dimensions. Fiber bundles of outer cortex $1.7-3.6 \mathrm{~mm}$ in radial extent; 
fibers $40-80 \mu \mathrm{m}$ in transverse diameter; intervening parenchyma $60-160 \mu \mathrm{m}$ in transverse diameter. $60-$ $280 \mu \mathrm{m}$ in height.

\section{Discussion}

The stem fragment described above, with a protostelic and deeply three-ribbed primary xylem surrounded by secondary tissues in "internodal" regions (i.e. approximately midway between levels of leaf trace departure), becoming dissected into two vascular segments with both primary and secondary tissues at corresponding "nodal" levels. is so far unique among early pteridosperms. The form of the trace-producing vascular segment is highly distinctive, appearing three-ribbed due to the presence of a pair of incipient traces plus evidently cauline primary xylem. The latter conlains a variable number of protoxylem strands related in part to total primary xylem volume.

A comparable three-ribbed vascular column has been observed in the type and only known specimen of Bostonia perplexa (Stein and Beck, 1978), agreeing not only in overall form but also in relative orientations of incipient traces and locations of protoxylem strands (Fig. 5). The differences noted between these two systems include a greater amount of secondary tissues as well as a somewhat larger maximum size of primary and secondary xylem tracheids in the new specimen described here. The number and placement of protoxylem strands and the total volume of primary xylem also differ, but all of these differences might be expected of genetic or ontogenetic variation within a single natural species.

It remains possible. of course, that the separate vascular segments observed in Bostomia and the specimen described here are instances of anomalous primary xylem dissection and or secondary development and, as a result. not grounds for conspecific assignment. Although we think this is unlikely, comparison will be made here with other potentially related forms. Besides Bostonia, the most similar species include Stenomyelon bifasciculare (Meyer-Berthaud, 1984). Galtiera hostonensis (Beck and Stein, 1987), Diichnia kentuckiensis (Read, 1936). and the early medullosan Quaestora amplecta (Mapes and Rothwell. 1980). All except Quaestora share with Bostonia and our new specimen the characteristic double vascular bundle supply to each leaf. Quaestora's leaf supply involves multiple bundles typical of medullosans (Mapes and Rothwell, 1980), but paired regions of leaf trace departure in this taxon suggest some similarity as well. The new material possesses a somewhat unusual but nevertheless typical Kalymmalike petiole, however, and lacks most characteristic medullosan features exhibited by Quaestora. As a result, emphasis will be placed here on comparison with the calamopityacean taxa.

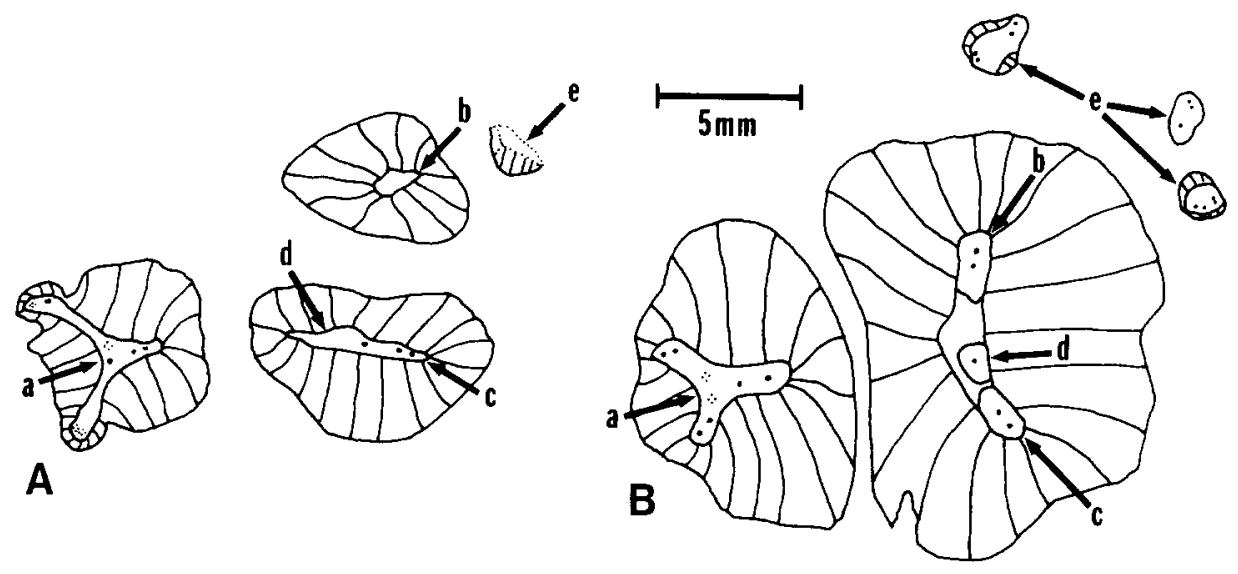

Fig. 5. Comparison of stelar systems in Bostonia perplexa. Scale bar $=5 \mathrm{~mm}$. (A) Camera lucida of primary and secondary xylem from section 2 of the type specimen. The drawing here shows slight differences from our original (Stein and Beck. 1978) in interpretation of number and locations of protoxylem strands. (B) Camera lucida of section B3 of the Cleveland Museum specimen P2001. In both specimens, correspondent tips of primary xylem ribs a-c: stelar center $d$ : correspondent petiole bundles $c$. 
In addition to several generalized calamopityacean features, Stenomyelon bifasciculare (MeyerBerthaud, 1984) shares with our new material a distinctly three-ribbed primary xylem system with tips of primary xylem ribs producing pairs of leaf traces in a manner reminiscent of the three-ribbed vascular segment described above. In S. bifasciculare. fewer protoxylem strands have been observed and, like protoxylem in other members of the genus Stenomyelon, may be mostly apparent at levels of leaf trace production (Meyer-Berthaud, 1984). This contrasts with our new specimen and other taxa in the Calamopityaceae where protoxylem strands are mostly conspicuous and appear to be longitudinally continuous throughout the stem. Some protoxylem strands in our new specimen, however, appear to be longitudinally discontinuous: the degree of similarity in architecture must await further analysis of $S$. bifasciculare (B. MeyerBerthaud, pers. commun., 1991). Stenomyelon bifasciculare is further distinguishable from our specimen by possessing larger petiole bases with a greater number of vascular bundles at equivalent levels. S. hifasciculare is also unusual among members of the Calamopityaceae in exhibiting conspicuous bordered pit-pairs on tangential as well as radial walls of secondary xylem tracheids. This feature, relatively rare in early seed plants, is more characteristic of secondary xylem in aneurophytalean progymnosperms (e.g. Stein and Beck, 1983) and may be primitive within the "lignophyte" clade (Doyle and Donoghue, 1986).

The organization of cauline protoxylem strands, especially the presence or absence of well-defined primary xylem and/or protoxylem "sympodia" like that seen in eusteles of extant seed plants, may ultimately be a key feature separating one or more natural groups of early seed plants. Among the Calamopityaceae. Diichnia kentuckiensis provides some of the clearest evidence of a pith surrounded by a well-defined system of primary xylem bundles that appear fully eustelic in comparison with modern forms (Read, 1936; Beck et al., 1992). There is little to suggest a close relationship with the protostelic specimen described here, as no coherent scheme of homology in protoxylem location, trace departure, and other features in all or part of Diichnia's vascular system with protostelic cala- mopityaceans, can yet be proposed. Diichnia's stelar architecture leads one to suspect a relationship for it with species of Calamopitys exhibiting a range of "mixed pith", but apparently eustelic, vascular systems. It is surprising, therefore, that Diichnia shares with the protostelic members of the Calamopityaceae the equally distinctive double origin of leaf traces (Fig. 7; see below).

Galtiera hostonensis, represented by a single specimen from the same Boston locality of the New Albany Shale as Bostonia, exhibits many similarities with our new specimen. Both have a deeply three-ribbed protostelic primary xylem system, with protoxylem strands in similar locations. and paired leaf traces (Fig. 6). In Galtiera, the primary xylem consists of a complex mixture of tracheids and parenchyma. Although not separating into discrete vascular segments, more than one level suggests the presence of significant amounts of xylem parenchyma between semi-discrete masses of tracheids. In addition, the secondary xylem in Galtiera is deeply fluted, involving embayments in the same regions where in our new specimen the primary xylem is enclosed by facing rows of secondary xylem tracheids. These similarities, not seen to such a degree in other taxa, are highly suggestive of basic homology. However, Galtiera shows no evidence of dissection of the primary xylem into multiple vascular segments, and shows no evidence of a three-ribbed central petiole bundle within its Kalvmma-like petiole base. In addition, although containing generally the same kinds of

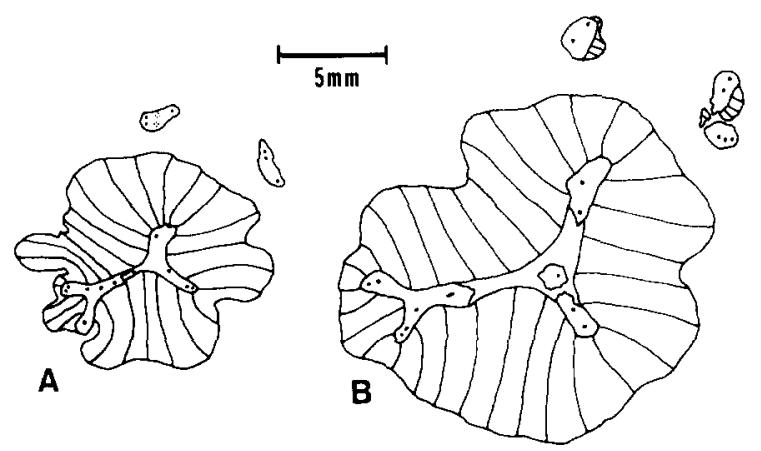

Fig. 6. Comparison of stelar systems of Galticra bostonensis (Beck and Stein, 1987) and Bostonia perplexa. (A) Camera lucida of primary and secondary xylem from section 118A of Galtiera. (B) Camera lucida of section $\mathrm{Cl}$ of Cleveland Museum specimen P2001. 
cortical tissues, Galtiera also contains many more masses of cells, perhaps sclereids or secretory cells, with local radial architecture. Among a range of interpretations, we compared this tissue with hyperplasia in phloem and other tissues resulting from viral infection (Beck and Stein, 1987). If correct, it is uncertain whether this histological difference would have systematic significance.

In addition to the above distinctions, most intriguing are possible differences between the two specimens in the primary vascular architecture. In Galtiera, a somewhat greater number of protoxylem strands have been interpreted at equivalent axis levels, and these are characteristically displaced towards the periphery of the primary xylem column (Beck and Stein, 1987, fig. 5). It is possible to interpret this distribution of strands as indicating the presence of discrete eustele-like sympodia (Beck and Stein, 1987), although the material is to some extent equivocal and other interpretations remain possible. In the specimen described above, by contrast, protoxylem strands are located nearer to the midplanes of the primary xylem ribs and. like aneurophytalean progymnosperms (Beck and Wight 1988), all may ultimately originate from a single protoxylem strand at the center of the stele (Fig. 1, C1, arrow $d$ ).

\section{Reinterpretation of Bostonia perplexa}

It appears that there are fundamental problems in assigning our new specimen to any calamopityacean taxon other than Bostonia perplexa. Assignment to Bostonia appears plausible, but there remains the significant possibility of false assignment because of the fragmentary nature of the type specimen. Significant features of our new specimen that might be added to the concept of Bostonia perplexa include: (1) an outer cortex with a cortical fiber system typical of the Calamopityaceae, (2) a Kalymma-type petiole base, including (3) a medial bundle that is three-ribbed, and (4) a stelar architecture consisting of more than one primary vascular segment at certain levels but fundamentally a three-ribbed protostele. In combining the two specimens into a single genus and species concept, key questions remain: how likely are the above features to have originally been present in the type, and at what taxonomic level are they significant? In our opinion, features (1) and (2) are likely to have been present in the type of Bostonia because they are ubiquitous within the better known members of the Calamopityaceae. Although important to document, they probably should not be considered diagnostic at the genus level. More important in assignment of the new specimen to Bostonia are (3) and (4). Unfortunately, no evidence can be brought to bear at present on whether the type of Bostonia bore the potentially unique form of Kalymma petioles described here. More readily addressed, however, is the likelihood of basic homology in stelar architecture between the two specimens.

Figure. 5 presents our view of correspondence in the two vascular systems. In both specimens, partially to completely discrete masses of tracheids are interpreted as comprising the tips of primary xylem ribs in a basically three-ribbed protostelic system (Fig. 5 arrows $a-c$ ). In addition, a tracheid mass representing the stelar center (Fig. 5, arrows d) may also be reflected to varying extents in both specimens. In the type specimen, each primary xylem rib tip occupies a different primary xylem segment enveloped by secondary tissues. One primary xylem rib (Fig. 5A, arrow c) plus the stelar center (Fig. 5A, arrow $d$ ) comprise the long-linear vascular segment. In the new specimen, by comparison, the tips of two primary xylem ribs (Fig. 5B, arrows $h$ and $c$ ) and the stelar center (Fig. 5B, arrow $d$ ) comprise a single vascular segment at most levels.

In both specimens, the trace-producing primary vascular segment is itself distinctly three-ribbed due to the presence of an incipient pair of leaf traces (Fig. 5, arrows $a$ ). This appearance is known to be ephemeral in the new specimen associated with a regular helical Fibonacci phyllotaxis. Distal to trace departure, the three-ribbed vascular segment undergoes reduction in size and complexity (Fig. 5B, arrow b). The type specimen may be similarly interpreted, with a conspicuous traceproducing vascular segment (Fig. 5A, arrow $a$ ) and a much reduced segment representing the tip of an adjacent primary xylem rib responsible for the vascular supply to the previous leaf in the ontogenetic helix (Fig. 5A, arrow h). Interestingly, the 
type specimen also shows evidence of vascular tissue at the periphery near this vascular segment (Fig. 5A, arrow e) in the appropriate position to be interpreted as one of an original pair of petiole bundles (Fig. 5B, arrows e). As interpreted here, the major differences between the two specimens appear to be in the degree of dissection of the primary vascular system, perhaps in part a reflection of relative numbers of tracheids versus xylem parenchyma, and in the total amount of secondary xylem.

\section{Bostonia and evolution of stelar form in the Calamopityaceae}

Read (1937) attempted the last comprehensive phylogenetic view of stelar features within the Calamopityaceae. His analysis, drawing on work by earlier authors, cited four major character complexes that continue to influence our view of this group: (1) a distinction between genera with pycnoxylic (Bilignea, Eristophyton, Endoxylon) versus manoxylic (Stenomyelon, Calamopitys, Diichnia) secondary xylem, suggesting groups with distant and possibly polyphyletic relationships, (2) a primitive mesarch order of primary xylem maturation with separate advancements toward endarchy in the pycnoxylic group and exarchy within Stenomyelon, (3) advancement toward "medullation" in the manoxylic group starting with protostelic, three-ribbed Stenomyelon and culminating in Diichnia, and (4) advancement in the manoxylic group toward the distinctive "dilacunar trace" of Diichnia.

Distinction (1) is now widely accepted (Lacey, 1953), although in recent years the degree of separation of the two groups, commonly termed "cycadophytic" versus "coniferophytic" seed plants, has been debated. Rothwell (1982) called into question the existence of distinct coniferophytic and cycadophytic lineages in the early history of the group as a result of finding little credible evidence of conifer-like plants in the Early Carboniferous. Long $(1979,1987)$ suggested the possibility that forms like Pitus and Eristophyton represent arborescent pteridosperms (presumably cycadophytic plants), but the question of specific relationship(s) was not examined. Galtier and Scott (1989) suggested that the pycnoxylic taxa may in fact comprise a natural group of $K$-selected early seed plants, but again specific relationships were not examined.

The remainder of Read's characters require redefinition, especially in light of more recent work on seed plant stelar architecture (Namboodiri and Beck, 1968; Beck et al., 1983) and phylogenetic interpretations of the origin of these systems from possible progymnosperm ancestors (Beck, 1981; Rothwell, 1982; Meyen, 1984). In recent years, the question of homology in stelar systems in the Calamopityaceae has also become considerably more complicated by the addition of the new taxa Stenomyelon bifasciculare (Meyer-Berthaud, 1984), Galtiera bostonensis (Beck and Stein, 1987), and Triichnia meyenii (Galtier and Beck, 1992) to the group, and the new interpretation of Bostonia perplexa proposed here.

Figures 7 and 8 provide an attempt to update Read's perspective on stelar evolution within the manoxylic Calamopityaceae using a cladistic approach. We feel that cladistic analysis on such a small scale, based on just two characters involving only aspects of stelar form, is useful here because these features comprise most of what is commonly asserted as evidence of relationships among members of the group. Our analysis is intended primarily to help focus this discussion within the logical framework that cladistics provides, and should be considered preliminary pending completion of work in progress on several of these taxa. For information on methods and terminology employed here, see Estabroook (1978, 1983), Meacham (1984), Stein et al. (1984), and Stein (1987). For clarity and convenience, we will use the term "convex" to denote groups that under some cladogram rooting may be considered either monophyletic (holophyletic) or paraphyletic (Estabrook, 1983). Use of the term serves to emphasize proximity and connectedness of proposed character states regardless of polarity assessments.

Stelar architecture is modelled as a three-state cladistic character (Fig. 7A) in which the primitive state comprises protosteles with ribbed columns of primary xylem, as exhibited by Stenomyelon spp. and Galtiera. A derived state is proposed to encompass Diichnia, Triichnia, and several species of 


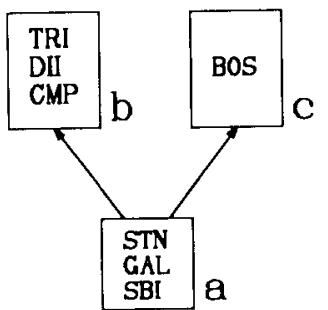

A $\#$ Stele

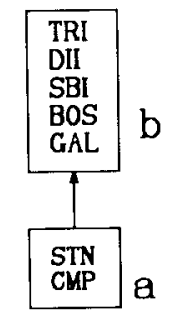

B 2 Leaf
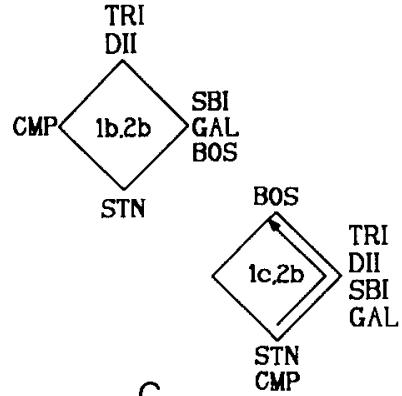

Fig. 7. Preliminary cladistic analysis of stelar evolution in the Calamopityaceae based upon two historically important characters. Taxa used in the analysis are: DII - Dichnia kentuckiensis, TRI - Triachnia meyenii, CMP - Calamopitys spp. BOS - Bostonia perplexa, STN--Stenomyelon spp. (excluding S. bifasciculare), GAL - Galticra bostonensis. SBI - Stenomvelon hifasciculare. (A) Evolution of the calamopityacean stele modelled as a three-state cladistic character. Protostelic and three-ribbed taxa (STN. GAL, SBI) comprise the primitive state, $a$, Eustelic taxa (CMP. DII. TRI) with varying amounts of 'mixed pith' comprise a derived state. h. Fundamentally protostelic, but dissected (BOS) comprises a separate derived state. c. (B) Evolution of calamopityacean leaf traces modelled as a two-state cladistic character. Taxa with leaf traces originating as a single bundle (STN. CMP) comprise the primitive state, a. Taxa with leaf traces originating from two (or more) bundles, possibly produced from more than one sympodium of the main axis vascular system (DII. TRI, SBI. BOS, GAL), comprise a derived state, $b$. (C) Analysis of compatibility of cladistic characters in (A) and (B). Distribution of taxa in the various states indicates incompatibility at the level of evolutionary transition from state $a$ to $b$ in both characters. Compatibility is noted. however, in comparing transition from $a$ to $c$ in character 1 with transition $a$ to $h$ in character 2. The unique pattern of character evolution inferred from the compatibility is indicated by arrow.
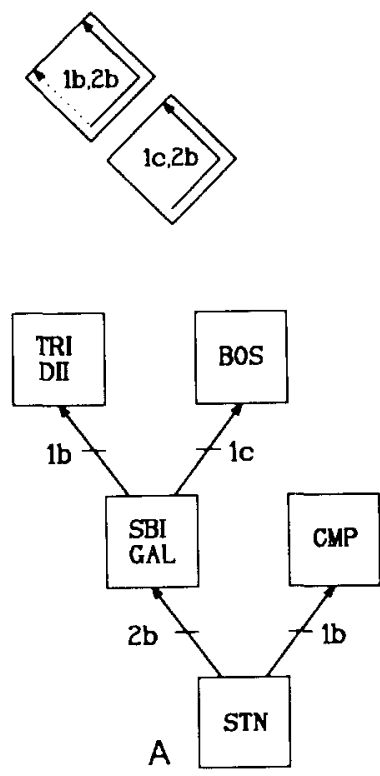
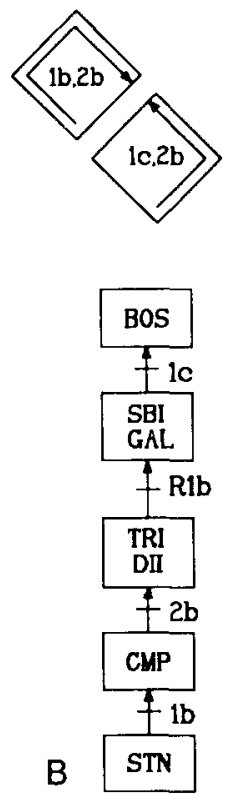

Fig. 8. Proposed resolutions of the incompatibility observed in Fig. 7; see text for discussion of the relative plausibility of these hypotheses. (A) Resolution suggesting single origin of paired leaf traces, $2 h$, parallelism in origin of the custele, $I h$, and single origin of dissected stele in Bostonia, lc. B. Resolution suggesting single origin of eustele. $1 b$, single origin of paired leaf traces, $2 h$, reversal to protosteles, $R / b$, and single origin of dissected stele in Bostomia, $l c$.
Calamopitys-genera with a variably dissected eustelic architecture and a probable sympodial system of protoxylem strands. Bostonia, with a dissected but non-eustelic primary vascular system, is interpreted as a separate derived state. At this point, no attempt will be made to segregate laxa within the protostelic state on the basis of locations of protoxylem strands or hypothesized sympodia since it is unclear how to propose realistic homologies in these features across all taxa.

Nodal anatomy and vascular trace architecture (Fig. 7B) is modelled here as a two-state cladistic character. Placed in the primitive state are Stenomyelon (excluding S. hifasculare) and Calamopity's [possibly excluding $C$. annularis (Galtier and Meyer-Berthaud, 1989)], all having leaf traces originating as a single vascular bundle probably derived from a single sympodium (if present) of the shoot vascular system. Placed in the derived state are Stenomyelon hifasculare. Bostonia, Galtiera, and Diichnia, all taxa in which the leaf vascular supply is derived proximally from a pair of leaf traces. In Diichnia, leaf traces arise from separate sympodia of the shoot vascular system (Beck et al.. 1991). Other members of this group. with the exception of Bostonia. might be similarly interpreted although definitive evidence pro or con 
remains to be collected. The basic similarity (probable homology) between all of these taxa, however, is remarkable. In this analysis, the three leaf trace system of Triichnia, derived from two points of origin, is considered a variant of the double-trace system of the Diichnia type.

Attempting to view the two cladistic characters jointly as phylogenetic estimators, a single incompatibility is observed in the use of derived states "eustele" and "paired traces" (Fig. 7C, indicating that at best only one of them, as proposed, is an historically accurate synapomorphy. In addition, it is easy to show by means of the matrix test (Estabrook. 1983) that no modification of polarity or proximity relations of the states of these characters is sufficient to resolve the incompatibility. Within the cladistic paradigm, only proposals of homoplasy permit a coherent interpretation.

Of the four simplest resolutions of the incompatibility involving single instances of parallelism or reversal in the characters, only two yield a result without encountering additional incompatibilities (Fig. 8). One resolution (Fig. 8A) suggests two origins of the eustelic condition (state $I b$ ), one within Calamopitys with leaf trace bundles derived from a single vascular bundle, and the other within the Diichnia plus Triichnia group with paired origin of the leaf traces. This phylogeny seems unrealistic, however, given evident similarity and considerable morphological overlap in mixed pith, protoxylem strand arrangement, and trace departure exhibited by Calamopitys, Diichnia, and Triichnia. If "eustele" is to be treated as a putative synapomorphy within this group. (other, primarily developmental interpretations remain possible), then it seems likely that these taxa comprise a convex group.

The second resolution (Fig. 8B) involves a single origin for both calamopityacean eusteles (state $1 b$ ) and paired trace departure (state $2 b$ ), followed by reversal from eustelic to protostelic shoot vascular systems in Galtiera, Stenomyelon bifasciculare, and Bostonia (state $R I b$ ). This resolution appears more realistic since it permits convexity of the Calamopitys, Diichnia, plus Triichnia group, but it suggests a basic non-homology between protosteles in $\mathrm{Gal}$ tiera, S. hifasciculare, and Bostonia, derived by reversal. and presumably primitive protosteles comprising the other species in the genus Stenomyelon. The latter hypothesis may be supported by the eustelic interpretation of protoxylem strands suggested for Galtiera (Beck and Stein. 1987), although Bostonia from this standpoint remains problematic. It is interesting to note that this phylogeny necessitates interpreting at least part of the evidence cited in support of the "Beck hypothesis" (Doyle and Donoghue, 1986) involving origin of seed plant eusteles from calamopityacean protosteles, in reverse (Beck and Stein, 1985).

It is clear that much remains to be done toward further refinement of these characters. In particular, it seems very important to know to what extent sympodial systems of protoxylem strands characterize all members of the Calamopityaceae. Calamopitys, Diichnia and Triichnia seem the most eustelic, with protoxylem strands occurring within semi-discrete bundles of tracheids mostly surrounding a "mixed pith". Protostelic and deeply three-ribbed Galtiera may, with difficulty, be interpreted in the same way, but similarities may also be suggested with protostelic and dissected Bostonia. The latter seems much more like protostelic aneurophytalean progymnosperms in architecture, although more complex. Other protostelic and "mixed-pith" taxa need to be analyzed in similar detail. Complicating comparison of protoxylem in all of these stelar systems is the question how much of the protoxylem should be considered "cauline" as opposed to "foliar", or even whether this distinction is relevant. Nor is it clear how to consistently interpret "reparatory strands" and other, sometimes longitudinally discontinuous, accessory protoxylem strands (Beck. 1970; Galtier. 1973; Beck et al., 1992).

\section{Bostonia and possible calamopityacean origin of medullosans}

In our previous paper on Bostonia (Stein and Beck, 1978), we argued for caution in interpreting a medullosan relationship for Bostonia because of its highly fragmentary condition. New data provided by this study have largely resolved the uncertainty surrounding Bostonia's stelar system, indicating the presence of semi-discrete vascular segments that are strikingly reminiscent of some 
medullosans. Looking within the Calamopityaceae, the dissected stele of Bostonia exhibits important similarities with Galtiera and Stenomyelon bifasciculare, all having deeply three-ribbed protosteles and paired origin of leaf traces. Bostonia may therefore suggest the origin of the Medullosales from within this protostelic group. A similar, but differently focused, phylogenetic hypothesis has already been advanced by Mapes and Rothwell (1980). These workers made a fairly explicit case for evolution of the medullosan petiole anatomy, consisting of a large number of vascular bundles, from the Calamopityaceae with simpler, but still multi-bundled, petioles of the Kalymma-type. They also hypothesized that with the exception of phyllotaxis, Quaestora represents the primitive condition for stelar features within medullosans, which may suggest medullosan origin from among protostelic members of the Calamopityaceae as well. In this section, we compare these ideas. Ideally, of course, the search for medullosan ancestors should involve comparisons of many vegetative and reproductive features across a wide range of early seed plants, not just members of the Medullosales and Calamopityaceae. In our opinion, however, there is insufficient knowledge of potentially relevant taxa and characters at present to make a fullfledged cladistic analysis meaningful. It is interesting to note, however, that very simple cladistic characters related specifically to the origin of medullosan derived condition in both petiolar structure (Fig. 9A) and vascular architecture (Fig. 9B), features that dominate both of these phylogenetic ideas, are incompatible (Fig. 9C). Interpretations of Bostonia as derived in having a medullosan dissected stelar form but primitive petiole type, and Quaestora with exactly the opposite states, are key factors in this incompatibility. Under the cladistic paradigm. again we must resort to interpretation of the conflict as homoplasy. We can enumerate the set of most parsimonious resolutions of the incompatibility involving single instances of parallelism or reversal (Fig. 9D). But which. if any, of these views is likely to be correct?

The complex trace departure and petiole structure of Quaestora, combined with other medullosan features such as extremely decurrent leaf bases, bilateral petiole bundle anatomy, resin rodlets, secretory canals, and complex histology of primary xylem and cortex, suggests that this form is a good medullosan (Mapes and Rothwell, 1980). In terms of the proposed resolutions, this argues for convexity of the group comprising Quaestora plus other medullosans (Fig. 9D, $I, I I I, I V$ ). Looking specifically at Quaestora, choosing among these resolutions requires deciding upon the validity of placing it in an ancestral relationship with respect to other medullosans.

Mapes and Rothwell (1980) argue that apart from decussate phyllotaxis, Quaestora's ribbed protostelic vascular architecture with a sympodial system of protoxylem strands might serve as a good candidate for the ancestral condition within, or leading to, medullosans, the latter distinction in our view dependent upon the order of acquisition of other medullosan features. Possibly arguing against this, however, is the developmental perspective that an opposite decussate phyllotaxis, involving multiple closely spaced superimposed leaves (contrasted with common helical Fibonacci systems tending to minimize leaf superposition), might reinforce development of primary xylem ribs along directions of trace departure (Wight, 1987; Stein and Hotton, 1991). This would suggest that the protostelic condition in Quaestora is not in itself a genetic trait inherited from some primitive medullosan or pre-medullosan ancestor, but a "spandrel" (Gould and Lewontin, 1979) - the passive consequence of an unusual phyllotaxis. Opposite-decussate branching and/or phyllotaxis, the presumed primary character in this case, may be observed in a number of groups including the aneurophytalean progymnosperm Tetraxylopteris (Beck. 1957) and the early seed plant Tetrastichia (Gordon, 1938), but because of its scattered occurrence it seems unlikely that a large group of progymnosperms and early seed plants share this feature as a synapomorphy. We agree with Mapes and Rothwell (1980), therefore, that oppositedecussate phyllotaxis is probably not primitive within the Medullosales, despite its relatively early occurrence in Quaestora. This developmental argument, although far from conclusive, favors resolution of the incompatibility by considering the stelar system of Quaestora to be an advancement within the Medullosales (Fig. 9D, III). 


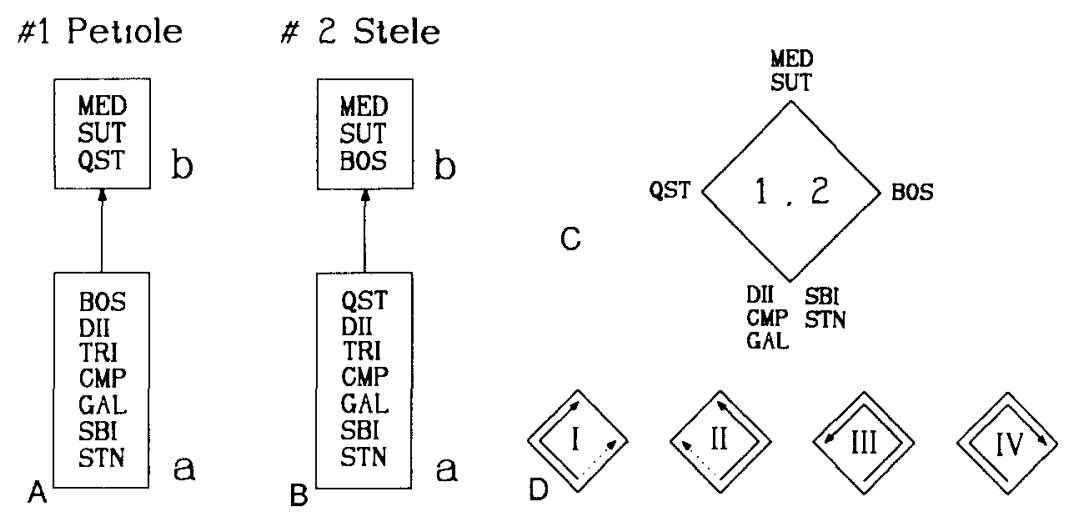

Fig. 9. Preliminary analysis of the significance of Bostonia with regard to a calamopityacean origin of Medullosales. See text for extensive amplification. Taxa are the same as in Fig. 6 plus representative medullosans: MED - Medullosa spp.. SUT - Sutcliffia insignis, and QST - Quaestora amplecta. (A) Evolution of vascular architecture of the petiole in Calamopityaceae and Medullosales. modelled as a two-state cladistic character. Members of the Calamopityaceae (BOS, DII, TRI, DMP, GAL, SBI, STN) with characteristic petioles of the Kalymma-type are considered to comprise the primitive state, $a$; members of the Medullosales with equally characteristic Myeloxylon-type petioles (MED, SUT, QST) comprise a derived state, $b$. (B) Using Bostonia as an argument for the calamopityacean origin of medullosan stelar systems, modelled as a two-state cladistic character. All taxa with protosteles plus calamopityacean taxa with eusteles and 'mixed pith' (QST, DII, TRI, CMP, GAL, SBI, STN) comprise the primitive state, $a$; taxa with Medullosa-like dissected stelar systems (MED, SUT, BOS), comprise a single derived state, $b$. (C) Incompatibility observed between characters defined in (A) and (B) Note critical positions occupied by QST and BOS. (D) Four simplest (most parsimonious) resolutions of the cycle in (C) involving single instances of homoplasy, either parallelism (= convergence), I, II, or reversal, III, IV

Considering Bostonia's contribution to the incompatibility, several features of vascular and cortical anatomy, in addition to the presence of a typical Kalymma-like petiole base, indicate convexity with other members of the Calamopityaceae (Fig. 9D, I-III). Distinguishing hypotheses of medullosan origin either from or parallel to Bostonia depends, therefore, almost entirely upon deciding whether possession of the multisegmented vascular condition in both accurately reflects inheritance from a common ancestor. In assessing the likelihood of this hypothesis, we believe there are two more or less separate considerations: (1) the likelihood of homology in the unusual organization of vascular cambium about the multiple primary xylem segments producing what has been termed "centripetal" (in addition to more typical "centrifugal") secondary vascular tissues. and (2) the likelihood of homology in distribution and composition of the primary vascular tissues themselves.

The majority of authors considering the medullosans from the monostelic perspective so far have interpreted "centripetal" secondary vascular tissues to be an unusual and potentially synapomorphic feature for the group (Crane, 1985; Doyle and Donoghue, 1986). In light of the dynamics of development, however, we suspect that this view is unlikely to be correct. There is increasing evidence that primary and secondary tissue organization in vascular plants develops in response to hormone (largely auxin) concentration gradients in the shoot, and that these concentration gradients can be traced directly to growth activity of hormone sources, primarily leaves, at the shoot tip (Scheckler, 1976, 1978; Lyndon, 1990; Stein and Hotton, 1991). From the perspective of the developing vascular cambium in a "polystelic" medullosan, or in Bostonia, the hormonal environment immediately adjacent to each primary vascular segment probably appears identical to the environment surrounding the entire stele in primitively protostelic calamopityacean taxa. A potential synapomorphy, if there is one to be found among early vascular plants, might more realistically be placed with eustelic seed plants where the vascular cambium fails to envelop each segment of primary xylem but instead possesses the new developmental capacity to organize both adjacent to, and between. components of the primary vascular system. Other interpretations are possible, of course, but from this perspective a proposed synapomorphy linking 
Bostonia with medullosans (Fig. 9B; D, $I I-I V$ ), considered on the basis of secondary xylem configuration. would be invalid.

Considering the origin of medullosan steles using primary tissues only, the dissected but otherwise apparently protostelic architecture of Bostonia again argues for convexity with members of the Calamopityaceae but offers little support for a medullosan relationship. Several authors have argued that in early seed plants, especially where there is a lack of one-for-one correspondence between primary vascular segments and protoxylem strands, the protoxylem more accurately reflects "fundamental" stelar architecture (Beck et al.. 1983). In Medullosa, protoxylem architecture has been hypothesized to comprise a system of sympodial strands, therefore essentially eustelic (Basinger et al., 1974). If true, then some more eustelic member of the Calamopityaceae, such as Calamopitys. Diichnia, or Triichnia might better serve as a candidate for medullosan ancestor than protostelic Bostonia. Depending on how this argument is implemented in a refined cladistic character. this perspective alone might be sufficient to resolve the incompatibility. However, at present we lack the comparative data for determining the level of universality of states based on protoxylem patterns alone. It is possible, for instance, to observe sympodial (and apparently eustele-like) patterns of protoxylem in living members of the Ophioglossaceae and Filicales (Chau, 1981). Thus, "eustelic protoxylem architecture" as a putative synapomorphy might basally delimit a larger group including some or all ferns plus seed plants. But are these similarities homologous, reflecting shared genetic and developmental patterns between the groups acquired from a common ancestor, or are they parallelisms resulting from developmental or structural constraint or even from pure chance?

Another concern is that, given current knowledge of primary vascular architecture in medullosans, it is not at all certain that the pattern of protoxylem is more than superficially similar to the eustelic pattern observed in other seed plant groups. The possibility that medullosan primary vascular systems are in fact fundamentally homologous with protostelic members of the Calamopityaceae with deeply three-ribbed columns of primary xylem, as observed in Galtiera and Bostonia, deserves further attention. In this context, it is interesting to note that some of the earliest multisegmented medullosans, including an unpublished form in the same sediments as Quacstora (work in progress), are of the Medullosa anglica-type, often (but not always) consisting of three vascular segments perhaps homologous to the primary xylem ribs in Bostonia.

Considering these arguments, there seems to be little compelling evidence for using either Quacstora or Bostonia as a candidate for medullosan ancestor (Stein, 1987). Nevertheless, in our opinion, medullosan ancestry from among the Calamopityaceae remains an attractive hypothesis With continuing work on calamopityacean specimens, however, we seem to be encountering an ever-widening range of variation, involving apparent intermediacy between previously defined morphs, and increasing conflict in the phylogenetic implications of important and relatively wellstudied characters - not less, as we might have hoped. It is unlikely, in our opinion, that simply widening the scope of cladistic study at this point to include other, generally less well-understood taxa and characters, will significantly improve the situation. The level of character conflict exhibited in important stelar features suggests to us that much of what might otherwise be interpreted as homoplasy under the cladistic paradigm in fact has an ontogenetic explanation reflecting only minor developmental shifts both within and between individuals at some basic level. The medullosan derived conditions in stele and leaf anatomy may well represent end-point morphologies somehow segregated from this complex ancestral developmental array. If true, then it appears that proposal of synapomorphies will not only have to be more refined than those used here, but will also have to be more explicitly keyed to underlying developmental processes. In our opinion. similar arguments probably apply to all cladistic characters regarding early seed plant relationships proposed to date. It seems increasingly unlikely that inference of phylogenetic relationships for early seed plants can proceed separately and in advance of understanding the evolutionary and developmental processes that gave rise to observed charac- 
ter patterns. All appear to be aspects of the same fundamentally multivariate problem.

\section{Acknowledgements}

We thank Shyamala Dinkar Chitaley for permitting work on the material described in this report. We also thank Jean Galtier, Brigitte MeyerBerthaud, and Carol Hotton for extended discussions on early seed plant structure and evolution, and Peter Crane. Jean Galtier, Gar Rothwell, and especially Richard Bateman for helpful comments on an earlier draft. This study was supported by National Science Foundation grants BSR-8113542 and INT-8914710 to C. B. Beck and W. E. Stein. and BSR 8306893 to W. E. Stein and C. B. Beck.

\section{References}

Arnold. C.A. 1948. Classification of gymnosperms from the vicwpoint of palcobotany. Bot. Gaz., 110:2-12.

Basinger, J.F., Rothwell. G.W. and Stewart. W.N., 1974. Cauline vasculature and leaf trace production in medullosan pteridosperms. Am. J. Bot., 61: 1002-1015.

Beck, C.B., 1957. Tetraxylopteris schmidtii gen. et sp. nov., a probable pteridosperm precursor from the Devonian of New York. Am. J. Bot., 44: 350-367.

Beck, C.B., 1970). The appearance of gymnospermous structure. Biol. Rev. 45: 379-400.

Beck. C.B.. 1976. Current status of the Progymnospermopsida. Rev. Palaeobot. Palynol., 21: 5-23.

Beck. C.B. 1978. Periastron reticulatum Unger and Aerocortex kemuckiensis, n. gen. et sp., from the New Albany shale of Kentucky. Am. J. Bot., 65: 221-235.

Beck. C.B. 1981. Archacopleris and its role in vascular plant cvolution. In: K.J. Niklas (Editor) Paleobotany, Paleoecology, and Evolution, 2. Praeger, New York. pp. 193-230.

Beck, C.B., 1985. Gymnosperm phylogeny - a commentary on the views of S. V. Meyen. Bot. Rev., 51: 273-294

Beck, C.B. and Stein, W.E., 1985. Eustelic protosteles in early seed plants'? Am. J. Bot. 72: 889-890.

Beck, C.B. and Stein, W.E., 1987. Galtiera bestonensis, gen. et sp. nov., a protostelic calamopityacean from the New Albany shake of Kentucky. Can. J. Bot., 65: 348-361.

Beck. C.B. and Wight. D.C.. 1988. Progymnosperms. In: C. B. Beck (Editor), Origin and Evolution of Gymnosperms. Columbia Univ. Press, New York, pp. $1-83$.

Beck, C.B., Schmid, R. and Rothwell, G.W., 1983. Stelar morphology and the primary vasculature architecture of seed plants. Bot. Rev., 48: 691-815.

Beck. C.B., Galtier. J, and Stein, W.E., 1992. A reinvestigation of Diichmia Read from the New Albany Shale of Kentucky. Palacontographica $\mathrm{B}$, in press.

(Chau. R., 1981. Vascular Morphology of the Ophioglossaceae. Ph.D. Thesis. Univ. Michigan. Ann Arbor.
Crane, P.R., 1985. Phylogenetic analysis of seed plants and the origin of angiosperms. Ann. Mo. Bot. Gard.. 72: 716-793.

Cross, A.T. and Hoskins, J.H., 1951a. Paleobotany of the Devonian-Mississippian black shales. J. Paleontol., 25 : $713-728$.

Cross, A.T. and Hoskins, J.H., 1951b. The Devonian-Mississippian transition flora of east-central United States. C. R. III Congr. Strat. Geol. Carbonifere, Heerlen, pp 113-122.

Doyle, J.A. and Donoghue, M.J., 1986. Seed plant phylogeny and the origin of angiosperms: an experimental cladistic approach. Bot. Rev., 52: 321-431.

Doyle. J.A., and Donoghue, M.J., 1987. The importance of fossils in elucidating seed plant phylogeny and macroevolution. Rev, Palaeobot. Palynol., 50: 63 95.

Drinnan, A.N., Schramke, J.M., and Crane. P.R., 1990. Stephanospermum konopeonus (Langford) comb. nov: a medullosan ovule from the Middle Pennsylvanian Mazon Creek flora of northeastern Illinois, U.S.A. Bot. Gaz., 151: $385-401$

Estabrook. G.F., 1978. Some concepts for the estimation of relationships in systematic botany. Syst. Bot., 3: 146-158.

Estabrook. G.F., 1983. The causes of character incompatibility. In: J. Felsenstein (Editor), Numerical Taxonomy (NATO ASI Ser. G1). Springer, Berlin, pp. 279-295.

Ettensohn, F.R.. Miller, M.L.. Dillman. S.B.. Elam, T.D., Geller, K.L.. Swager. D.R., Markowitz, G.. Woock and R.D.. Barron. L.S., 1988. Characterization and implications of the Devonian-Mississippian black shale sequence. eastern and central Kentucky, USA: Pycnoclines, transgression. regression, and tectonism. Devonian of the World. Proc. II Int. Symp. Devonian System, Calgary, Canada, (C.S.P.G. Mem. 14, II.) pp. 323-345.

Galtier, J. 1973. Remarques sur l'organisation et la signification phylogenetique de la stele des Calamopityacees. C. R Acad. Sc. Paris, 276: 2147-2150.

Galtier. J., 1986. Morphologie vegetative des progymnospermes et pteridospermales du Paleozoique. Naturalia monspeliensia: $495-505$.

Galtier, J., 1988. Morphology and phylogeny of early pteridosperms. In: C.B. Beck (Editor), Origin and Evolution of Gymnosperms. Columbia Univ. Press, New York, pp. $135-176$.

Galtier, J. and Beck, C.B.. 1992. Triichnia. a new eustelic calamopityacean from the lower Carboniferous of France. Palaeontographica B. 224: 1-16.

Galtier, J. and Meyer-Berthaud, B., 1989. Studies of the early Carboniferous pteridosperm Calamopitys -... a redescription of the type material from Saalfeld (GDR). Palaeontographica B. $213: 1-36$

Galtier, J. and Scott, A., 1989. On Eristophyton and other gymnosperms from the lower Carboniferous of Castelton Bay. East Lothian, Scotland. Geobios, 23: 5-19.

Galtier. J. and Scott. A., 1991. Stantroodia, a new genus of probable early gymnosperms from the Dinantian of East Kirkton. Scotland. Trans. R. Soc. Edinburgh: Earth Sc. 82: 113-123.

Gordon, W.T., 1938. On Tetrastichia bupaides: a Carboniferous pteridosperm from East Lothian. Trans. R. Soc. Edinburgh, 59: $351-370$.

Gould. S.J. and Lewontin, R.C., 1979. The spandrels of San Marco and the panglossian paradigm: a critique of the 
adaptionist programme. Proc. R. Soc. London Ser. B, 205: $581-598$.

Hoskins, J.H, and Cross, A.T., 195Ia. The petrifaction flora of the Devonian-Mississippian black shale. Palaeobotanist, 1, Sahni Mem. Vol., Lucknow, pp. 215-238.

Hoskins. J.H. and Cross. A.T., 195lb. The structure and classification of four plants from the New Albany shale. Am. Mid. Nat., 46: 684-716.

Kidston, R. and Gwynne-Vaughan, D.T., 1912. On the Carboniferous flora of Berwickshire. I. Stenomvelon tudiamum. Trans. R. Soc. Edinburgh, 48: 263-271.

Lacey. W.S., 1953. Scottish Lower Carboniferous plants: Erislophyzon waltoni sp. nov. and Endoxylon zonatum (Kidston) Scott from Dunbartonshire. Ann. Bot., 17: 579-596.

Lyndon. R.F., 1990. Plant Development. Unwin Hyman. London, $320 \mathrm{pp}$.

Mapes, G. and Rothwell, G.W., 1980. Quaestora amplecta gen. et sp. n., a structurally simple medullosan stem from the Upper Mississippian of Arkansas. Am. J. Bot., 67: 636-647.

May. B.I. and Matten, L.C. 1983. A probable pteridosperm from the uppermost Devonian near Ballyheigue, Co. Kerry, Ireland. Biol. J. Linn. Soc., 86: 103-123.

Meacham. C.A.. 1984. Evaluating characters by character compatibility analysis. In: T. Duncan and T. Stuessy (Edi1ors). Cladistics: Perspectives on the Reconstruction of Evolutionary History. Columbia Univ. Press. New York. pp. 152-165.

Meyen. S.V.. 1984. Basic features of gynnosperm systematics and phylogeny as evidenced by the fossil record. Bot. Rev., 50: $1-111$.

Meyen, S.V., 1986. Gymnosperm systematics and phylogeny: a reply to commentaries by C. B. Beck, C. N. Miller, and G. W. Rothwell. Bot. Rev. 52: 300-320.

Meyer-Berthaud, B., 1984. Stenomyelon from the Upper Tournaisian of the Montagne Noire (France). Can. J. Bot., 62: 2297.2307

Miller, C.N., 1985. A critical review of S. V. Meyen's "Basic features of gymnosperm systematics and phylogeny as evidenced by the fossil record". Bot. Rev., 51: 295-318.

Namboodiri. K.K. and Beck, C.B., 1968. A comparative study of the primary vasculature system of conifers. III. Stelar evolution in gymnosperms. Am. J. Bot., 55: 464-472.

Read, C.B., 1936. The flora of the New Albany shale, 1. Diic/mia kentuckiensis, a new representative of the Calamopityeac. U. S. Geol. Surv. Prof. Pap., 185-H: 149-161.

Read, C.B., 1937. The flora of the New Albany shale. 2. The Calamopityeae and their relationships. U. S. Geol. Surv. Prof. Pap.. 186-E: 81-104

Retallack, G.J.. and Dilcher. D.L., 1988. Reconstructions of selected seed ferns. Ann. Mo. Bot. Gard., 75: 1010-1057.

Rothwcll, G.W.. 1976. Primary vasculature and gymnosperm systematics. Rev. Palaeobot. Palynol., 22: 193-206.

Rothwell. G.W., 1982. New interpretations of the earliest conifers. Rev. Palaeobot. Palynol., 37: 7-28.

Rothwell, G.W.. 1985. The role of comparative morphology and anatomy in interpreting the systematics of fossil gymnosperms. Bot. Rev., 51: 319-327.

Rothwell, G.W., and Erwin. D.M., 1987. Origin of seed plants an aneurophyte/seed-fern link elaborated. Am. J. Bot.. 74 970-973.

Scheckler, S.E., 1976. Ontogeny of progymnosperms. 1. Shoots of Upper Devonian Aneurophytales. Can. J. Bot., 54 202-219.

Scheckler, S.E., 1978. Ontogeny of progymnosperms. II. Shoots of Upper Devonian Archaeopteridales. Can. J. Bot., 56 $3136-3170$.

Scott. A.C.. Galtier, J. and Clayton, J.. 1984. Distribution of anatomically-preserved floras in the Lower Carboniferous in Western Europe. Trans. R. Soc. Edinburgh: Earth Sc.. 75 $311-340$

Scott, D.H., 1923. Studies in Fossil Botany, 2. Spermatophyta. Hafner, New York, 446 pp.

Smoot, E.L. and Taylor, T.N., 1981. The petrified pteridosperm stem Medullosa anglica from the Pennsylvanian of North America. Palaeontology, 24: 647-653

Stein, W.E., 1987. Phylogenetic analysis and fossil plants. Rev. Palaeobot. Palynol. 50: $31 \cdots 61$

Stein. W.E. and Beck, C.B., 1978. Bostomia perplexa gen. et sp. nov., a calamopityacean axis from the New Albany shale of Kentucky. Am. J. Bot., 65: 459-465.

Stein. W.E. and Beck, C.B., 1983. Trilohoxilon arnoldii from the Middle Devonian of western New York. Contrib. Mus. Paleontol. Univ. Mich.. 26: 257-288.

Stein. W.E. and Beck. C.B., 1986. An idealized external reference system for the determination of phyllotaxis. Am. J. Bot. 73: 707-708.

Stein, W.E. and Beck. C.B., 1987. Paraphyletic groups in phylogenetic analysis: Progymnospermopsida and Prephanerogames in alternative views of seed plant relationships. Bull. Soc. Bot. Fr, 134: 107-119.

Stein, W.E. and Hotton, C.L., 1991. Modeling stelar architecture. Am. J. Bot., 78: 124.

Stein, W. E., Wight, D.C. and Beck, C.B., 1982. Techniques for preparation of pyrite and limonite permineralizations Rev. Palaeobot. Palynol., 36: 185-194.

Stein. W. E. Wight, D.C. and Beck. C.B., 1984. Possible alternatives for the origin of Sphenopsida. Syst. Bot.. 9 $102-118$

Stewart. W.N., 1983. Paleobotany and the Evolution of Plants Cambridge Univ. Press, Cambridge, $405 \mathrm{pp}$.

Taylor, T.N.. 1981. Paleobotany. McGraw-Hill. New York $589 \mathrm{pp}$.

Taylor, T.N. and Eggert, D.A., 1967. Petrified plants from the Upper Mississippian (Chester series) of Arkansas. Trans. Am. Microsc. Soc., 86: 412-416.

Unger, F., 1856. Beitrage zur Palaontologie des Thuringer Waldes. 2. Schiefer und Sandsteinflora. Denkschr. K. Akad Wien. Sitzungsber.. 11: 139-186

Wight, D.C. 1987. Non-adaptive change in early land plant evolution. Paleobiology, 13: 208-214. 